\title{
ECONOMIC TRACKING PORTFOLIOS
}

Owen Lamont

Working Paper 7055

http://www.nber.org/papers/w7055

\author{
NATIONAL BUREAU OF ECONOMIC RESEARCH \\ 1050 Massachusetts Avenue \\ Cambridge, MA 02138 \\ March 1999
}

I thank Nicholas Barberis, Rob Bliss, John Cochrane, Eugene Fama, Wayne Ferson, Larry Glosten, Ming Huang, and workshop participants at the Columbia Business School, MIT Sloan, NBER Asset Pricing Conference, Stanford University, Stockholm School of Economics, University of Chicago, University of Washington, Vanderbilt University, and the Yale School of Management for helpful comments. I am especially grateful for comments and collaboration from Christopher Polk. I thank Mark Carhart and Eugene Fama for providing data. I thank David Robinson and Kevin Qing Wang for research assistance, and the Center for Research in Security Prices, the FMC Faculty Research Fund, and the National Science Foundation for financial support. The views expressed in this paper are those of the authors and do not reflect those of the National Bureau of Economic Research.

( 1999 by Owen Lamont. All rights reserved. Short sections of text, not to exceed two paragraphs, may be quoted without explicit permission provided that full credit, including ${ }^{\circledR}$ notice, is given to the source. 
Economic Tracking Portfolios

Owen Lamont

NBER Working Paper No. 7055

March 1999

JEL No. E17, E44, G11

\begin{abstract}
An economic tracking portfolio is a portfolio of assets with returns that track an economic variable. Monthly returns on stocks and bonds are useful in forecasting post-war US output, consumption, labor income, inflation, stock returns, bond returns, and Treasury bill returns. These forecasting relationships define portfolios that track market expectations about future economic variables. Using tracking portfolio returns as instruments for future economic variables substantially raises the estimated sensitivity of asset prices to news about future economic variables. Out-ofsample results show that tracking portfolios are useful in forecasting macroeconomic variables and hedging economic risk.
\end{abstract}

Owen Lamont

Graduate School of Business

University of Chicago

1101 E. 58th St

Chicago IL 60637

and NBER

owen.lamont@gsbpop.uchicago.edu 
Changes in asset prices reflect, among other things, changing information about future economic conditions. Identifying the impact of different macroeconomic shocks on asset prices is important because it can reveal sources of economic fluctuations, measure risk premia, and help predict future economic fluctuations. Economic tracking portfolios are a way of connecting asset prices with news about economic variables. An economic tracking portfolio is a portfolio of assets whose returns track an economic variable, such as expected output, inflation, or returns.

The portfolios constructed here have unexpected returns with maximum correlation with news about future macroeconomic variables. I call these "economic tracking" portfolios, rather than "factor mimicking" portfolios, to make clear that these portfolios are not only useful for explaining the statistical properties (means and covariances) of asset returns, but are fundamentally economic in nature.

Empirical finance has a long tradition of explaining current returns with other current returns. A second tradition is to try to explain returns with contemporaneous economic variables, or with future economic variables, or with both (e.g. Chen, Roll, and Ross (1986), Fama (1990), and Campbell and Ammer (1993)). Economic tracking portfolios represent a middle ground between these two alternatives. On the one hand, tracking portfolios are asset returns. On the other hand, they are returns with an interpretable economic content. Constructing economic tracking portfolios is a way of using current asset returns as instruments for changes in expectations of future variables. The use of instruments is required because realized variables are noisy measures of innovations in expectations.

This paper builds on Breeden, Gibbons, and Litzenberger (1989). They construct economic tracking portfolios (which they call "maximum correlation portfolios") for current 
consumption, in order to test the Consumption Capital Asset Pricing Model (CCAPM). This paper has several differences. First, and most importantly, it constructs tracking portfolios for future (not current) economic variables, since asset returns reflect information about future cash flows and discount rates. Second, as a consequence, it uses only the unexpected component of returns (not total returns) in constructing the tracking portfolios. Last, it constructs tracking portfolios for a variety of economic variables (not just consumption).

Tracking portfolios have several uses. One use is measuring risk premia. If tracking portfolios earn risk premia, then the signs of the risk premia and the identities of the premiagenerating economic variables can reveal which state variables are important determinants of expected returns, and can help evaluate asset pricing models. Tracking portfolio have (at least) three other uses that do not rely on the portfolios earning non-zero risk premia.

First, tracking portfolios can serve as hedging tools for individuals who wish to insure themselves against a particular economic risk. For example, individuals who wish to insure against inflation could take a position in the inflation tracking portfolio. Second, tracking portfolios forecast economic variables. Since asset returns are available on a daily basis, tracking portfolios can provide daily information about the market's expectations about future economic variables. Third, by measuring innovations in expectations, tracking portfolios illuminate the structure of the economy and the reaction of prices to economic news. This paper concentrates on this last use of tracking portfolios, and studies the reaction of stock and bond prices to news about future production, interest rates, and expected returns.

These three uses are empirically testable, and do not depend on a particular asset pricing model. For example, suppose the CAPM is true. In that case, an economic tracking portfolio 
would have an expected return that is a linear function of covariance with the market, but its unexpected return would still reveal news about future economic variables. Alternatively, suppose that asset markets are inefficient, irrational sentiment affects market prices, and returns are partially predictable. In this case, as long as asset prices reflect some information about future economic variables, tracking portfolio returns will still be useful for hedging, forecasting, and understanding the economy.

This paper is organized as follows. Section 1 defines tracking portfolios, states their statistical properties, and introduces the notation. Section 2 discusses the relation of tracking portfolios to previous research. Section 3 describes the data. Section 4 shows the properties of the estimated tracking portfolios. Section 5 uses tracking portfolios to test hypotheses about the effect of news on asset prices. Section 6 shows the out-of-sample tracking ability of the portfolios, and performs robustness tests. Section 7 concludes by summarizing the results and discussing possible applications and extensions of tracking portfolios.

\section{Definitions and basic properties}

\section{Simple tracking portfolios}

A tracking portfolio for any variable y can be obtained as the fitted value of a regression of $y$ on a set of base asset returns. The portfolio weights for the economic tracking portfolio for $\mathrm{y}$ are identical to the coefficients of an OLS regression. If y happens to be to be a state variable for asset pricing, then a multi-factor model holds with one of the factors being y's tracking portfolio (Breeden, 1979). However, even if y is not a state variable for asset pricing, its tracking portfolio is still an interesting economic object, since it reveals changes in market expectations about y. 
The following three statements are equivalent descriptions of an economic tracking portfolio. Out of all possible linear combinations of the base asset returns, the portfolio: (a) has the minimum variance out of all portfolios with a given beta (univariate regression coefficient) in a regression of portfolio return on y; (b) has returns with the maximum possible correlation with $\mathrm{y}$; (c) has the highest R-squared in a univariate regression of y on returns.

Breeden, Gibbons, and Litzenberger (1989) show with matrix algebra the equivalence of these three properties, and it is worth showing the intuition even more simply. Let $\mathrm{r}$ be the return on a portfolio of base assets, $r=b R$ where $b$ is a vector of portfolio weights and $\mathrm{R}$ is a vector of returns on a set of base assets. The tracking portfolio is defined as the portfolio with weights that minimize the variance of the tracking portfolio given its loading on $y$. In other words, pick $b$ to minimize $\sigma_{r}^{2}$ given $\beta=\bar{\beta}$ (where $\beta \equiv \frac{\sigma_{r y}}{\sigma_{y}^{2}}$ is the coefficient in a regression of $\mathrm{r}$ on $\mathrm{y}$ ).

Since $\beta=\rho \frac{\sigma_{r}}{\sigma_{y}}$, minimizing $\sigma_{r}^{2}$ is equivalent to minimizing $\left(\bar{\beta} \frac{\sigma_{y}}{\rho}\right)^{2}$, which is equivalent to maximizing $\rho^{2}$ (where $\rho$ is the correlation of $y$ and $r$ ). Since the R-squared from a univariate regression is simply $\rho^{2}$, and since OLS also maximizes R-squared, the solution to this maximization problem is identical to an OLS regression.

\section{Tracking portfolios for news}

This paper constructs portfolios with unexpected returns which are maximally correlated with unexpected components of future $y$. Specifically, the target variable is "news" about $\mathrm{y}_{\mathrm{t}+\mathrm{k}}$, where $\mathrm{y}_{\mathrm{t}+\mathrm{k}}$ is a macroeconomic variable such as the inflation rate in period $\mathrm{t}+\mathrm{k}$. News is innovations in expectations about $\mathrm{y}_{\mathrm{t}+\mathrm{k}}$ with notation $\Delta \mathrm{E}_{\mathrm{t}}\left[\mathrm{y}_{\mathrm{t}+\mathrm{k}}\right] \equiv \mathrm{E}_{\mathrm{t}}\left[\mathrm{y}_{\mathrm{t}+\mathrm{k}}\right]-\mathrm{E}_{\mathrm{t}-1}\left[\mathrm{y}_{\mathrm{t}+\mathrm{k}}\right]$. For example, 
$\Delta \mathrm{E}_{\mathrm{t}}\left[\mathrm{y}_{\mathrm{t}+\mathrm{k}}\right]$ might be the news that the market learns in July 1980 about the inflation rate between July 1980 to July 1981.

The tracking portfolio returns are $\mathrm{r}_{\mathrm{t}-1, \mathrm{t}}=\mathrm{b} \mathrm{R}_{\mathrm{t}-1, \mathrm{t}}$, where $\mathrm{r}_{\mathrm{t}-1, \mathrm{t}}$ and $\mathrm{R}_{\mathrm{t}-1, \mathrm{t}}$ are returns from the end of period t- 1 to the end of period t. The tracking portfolio is constructed using unexpected returns on the base assets. Unexpected returns are actual returns minus expected returns, with notation $\tilde{\mathrm{R}}_{\mathrm{t}-1, \mathrm{t}} \equiv \mathrm{R}_{\mathrm{t}-1, \mathrm{t}}-\mathrm{E}_{\mathrm{t}-1}\left[\mathrm{R}_{\mathrm{t}-1, \mathrm{t}}\right]$. The portfolio weights, $\mathrm{b}$, are chosen so that $\tilde{\mathrm{r}}_{\mathrm{t}-1, \mathrm{t}}$ is maximally correlated with $\Delta \mathrm{E}_{\mathrm{t}}\left[\mathrm{y}_{\mathrm{t}+\mathrm{k}}\right]$.

Estimating tracking portfolios for news is only slightly more complicated than estimating simple tracking portfolios. One can always write a projection equation of news on unexpected returns. The key assumption in this paper is that innovations in returns reflect innovations in expectations about future variables, so that a is non-zero in the projection equation:

$$
\Delta \mathrm{E}_{\mathrm{t}}\left[\mathrm{y}_{\mathrm{t}+\mathrm{k}}\right]=\mathrm{a} \tilde{\mathrm{R}}_{\mathrm{t}-1, \mathrm{t}}+\eta_{\mathrm{t}}
$$

where $\eta_{t}$ as the component of news that is orthogonal to unexpected returns. Since unexpected asset returns reflect news about future cash flows and discount rates, the vector a will generally be non-zero for any variable that is correlated with future cash flows and discount rates.

As equation (1) is written, it seems as if one needs to obtain $\Delta \mathrm{E}_{\mathrm{t}}\left[\mathrm{y}_{\mathrm{t}+\mathrm{k}}\right]$, the period $\mathrm{t}$ news, in order to run the regression. Fortunately, this daunting task is not necessary in order to construct a tracking portfolio for news. All that is needed is $\tilde{R}_{t-1, t}$, unexpected returns in period t.

The realization of $\mathrm{y}_{\mathrm{t}+\mathrm{k}}$ can be written as the sum of the expectation in period $\mathrm{t}-1$, the innovation in expectations occurring in period $t$, and the innovation in expectations from period $t$ 
to period $\mathrm{t}+\mathrm{k}$ :

$$
\mathrm{y}_{\mathrm{t}+\mathrm{k}}=\mathrm{E}_{\mathrm{t}}\left[\mathrm{y}_{\mathrm{t}+\mathrm{k}}\right]+\mathrm{e}_{\mathrm{t}, \mathrm{t}+\mathrm{k}}=\mathrm{E}_{\mathrm{t}-1}\left[\mathrm{y}_{\mathrm{t}+\mathrm{k}}\right]+\Delta \mathrm{E}_{\mathrm{t}}\left[\mathrm{y}_{\mathrm{t}+\mathrm{k}}\right]+\mathrm{e}_{\mathrm{t}, \mathrm{t}+\mathrm{k}}
$$

The second assumption made here is that expected returns on the base assets in period $t$ are linear functions of $\mathrm{Z}_{\mathrm{t}-1}$, a vector of control variables known at period $\mathrm{t}-1$ :

$$
\mathrm{E}_{\mathrm{t}-1}\left[\mathrm{R}_{\mathrm{t}-1, \mathrm{t}}\right]=\mathrm{dZ} \mathrm{t}-1
$$

While the assumption in equation (3) is a potential source of model misspecification, one might expect the empirical results to be relatively robust to this form of misspecification, since asset returns are largely unpredictable at short horizons.

Last, for notational convenience, define the projection equation of lagged expectations of y on the lagged control variables:

$$
\mathrm{E}_{\mathrm{t}-1}\left[\mathrm{y}_{\mathrm{t}+\mathrm{k}}\right]=\mathrm{f} \mathrm{Z}_{\mathrm{t}-1}+\mu_{\mathrm{t}-1}
$$

Combining (1) - (4) results in the representation:

$$
\mathrm{y}_{\mathrm{t}+\mathrm{k}}=\mathrm{bR}_{\mathrm{t}-1, \mathrm{t}}+\mathrm{c} \mathrm{Z}_{\mathrm{t}-1}+\varepsilon_{\mathrm{t}, \mathrm{t}+\mathrm{k}} \text {. }
$$

where $\mathrm{b}=\mathrm{a}, \mathrm{c}=\mathrm{f}-\mathrm{ad}$, and $\varepsilon_{\mathrm{t}, \mathrm{t}+\mathrm{k}}=\eta_{\mathrm{t}}+\mu_{\mathrm{t}-1}+\mathrm{e}_{\mathrm{t}, \mathrm{t}+\mathrm{k}}$. Equation (5) is regression equation with realized future $y$ on the left hand side and period t returns and period $t-1$ control variables on the right hand side. It is consistent because the three components of $\varepsilon_{\mathrm{t}, \mathrm{t}+\mathrm{k}}$ are all by definition orthogonal to both $\mathrm{R}_{\mathrm{t}-1, \mathrm{t}}$ and $\mathrm{Z}_{\mathrm{t}-1}$.

The OLS regression defined by equation (5) produces $b R_{t-1, t}$, the portfolio having unexpected components maximally correlated with $\Delta \mathrm{E}_{\mathrm{t}}\left[\mathrm{y}_{\mathrm{t}+\mathrm{k}}\right]$. This paper estimates equation (5) and examines the properties of the resulting tracking portfolios. Equation (5) is completely atheoretical and depends only on the assumptions that changes in expectations about future $y$ are reflected in asset returns, and that expected asset returns are a function of the lagged control 
variables.

Here I make several comments on empirical implementation of equation (5). First, this paper uses zero cost portfolio returns for $\mathrm{R}_{\mathrm{t}-1, \mathrm{t}}$. Using zero cost portfolios means that there is no need to impose the restriction that the portfolio weights in $b$ add to anything. The resulting tracking portfolio is zero cost because it is a linear combination of zero cost portfolios.

Second, this paper uses monthly returns for the base assets. One should be careful using longer horizons for base assets (such as annual returns), since as horizons lengthen, return predictability rises (see Campbell (1991)), and the estimates might become more sensitive to violations of equation (3).

Third, one wants to pick base asset returns that are informative about changes in expectations about future $\mathrm{y}$. It is important that the different assets have different sensitivities to future $y$, so that the regression can pick the linear combination of returns that hedges out common sources of return variation that are unrelated to future $y$.

Fourth, the main reason to include control variables is to model expected returns, so $\mathrm{Z}_{\mathrm{t}-1}$ should include variables that forecast base asset returns. If asset returns were completely unpredictable, or if $E_{t-1}\left[R_{t-1, t}\right]$ were uncorrelated with $E_{t-1}\left[y_{t+k}\right]$, then one would not need any control variables. A secondary role for the lagged control variables in equation (5) is to help explain future $\mathrm{y}$. By including variables in $\mathrm{Z}_{\mathrm{t}-1}$ that are correlated with $\mathrm{E}_{\mathrm{t}-1}\left[\mathrm{y}_{\mathrm{t}+\mathrm{k}}\right]$, one can decrease the variance of the residual in equation (5), and thus gain more precise estimates of $b$.

Fifth, adding variables to $\mathrm{R}_{\mathrm{t}-1, \mathrm{t}}$ and $\mathrm{Z}_{\mathrm{t}-1}$ is not costless, since more variables raise the problem of overfitting, poor out-of-sample performance, and spurious inferences. 


\section{Relation to previous research}

One use of economic tracking portfolios is to hedge economic risk using existing assets. An alternative approach is to create entirely new assets indexed to economic variables. Shiller (1993), Shiller and Athanasoulis (1995), and Davis and Willen (1998) discuss the creation of these new assets and the resulting welfare gains. Economic tracking portfolios using existing liquid assets should make such financial innovation easier because tracking portfolios help the issuers of new securities partially hedge their exposure to economic risk.

Another use of economic tracking portfolios is to understand the connection between economic variables and asset prices. Previous research has drawn this connection in three ways: using current economic variables, using future economic variables, and using both via vector autoregression models.

\section{Contemporaneous macroeconomic variables}

The first approach involves regressing asset returns on contemporaneous economic variables. Examples of this approach include Chen, Roll, and Ross (1986) and numerous papers testing the CCAPM. Chen, Roll, and Ross (1986) find that covariance with industrial production growth, inflation, and bond market returns all lead to risk premia.

Unfortunately, attempts to identify factor mimicking portfolios for macroeconomic variables have been disappointing. Chan, Karceski, and Lakonishok (1998) construct portfolios by sorting stocks on monthly contemporaneous correlations over a five-year estimation period. They form portfolios based on inflation and industrial production. After examining these returns, they conclude that the macroeconomic factors are basically noise, and are not distinguishable from randomly generated portfolios. 


\section{Future macroeconomic variables}

The second approach involves regressing current returns on future realizations of economic variables. Examples of this approach include Fama $(1981,1990)$ and Schwert (1990), who seek to evaluate how much of the variance of returns on some test asset, $\mathrm{r}_{\mathrm{t}-1, \mathrm{t}}^{\mathrm{T}}$, is due to news about future economic conditions.

The relationship that this approach would like to estimate is:

$$
\mathrm{r}_{\mathrm{t}-1, \mathrm{t}}^{\mathrm{T}}=\mathrm{a}_{1} \Delta \mathrm{E}_{\mathrm{t}}\left[\mathrm{y}_{\mathrm{t}+\mathrm{k}}\right]+\mathrm{a}_{2} \mathrm{Z}_{\mathrm{t}-1}+\mathrm{u}_{\mathrm{t}}
$$

where again $\mathrm{Z}_{\mathrm{t}-1}$ measures expected returns on the test asset. The error term $\mathrm{u}_{\mathrm{t}}$ reflects test asset returns that are not related to changes in expectations about $\mathrm{y}$.

Since $\Delta \mathrm{E}_{\mathrm{t}}\left[\mathrm{y}_{\mathrm{t}+\mathrm{k}}\right]$ is unobservable, the regression that this approach actually runs is to substitute realizations of future y for the news term in equation (6):

$$
\mathrm{r}_{\mathrm{t}-1, \mathrm{t}}^{\mathrm{T}}=\mathrm{a}_{1} \mathrm{y}_{\mathrm{t}+\mathrm{k}}+\mathrm{a}_{2} \mathrm{Z}_{\mathrm{t}-1}+\mathrm{v}_{\mathrm{t}}
$$

Using equation (2), $v_{t}=u_{t}-a_{1} E_{t-1}\left[y_{t+k}\right]-a_{1} e_{t, t+k}$. Since $v_{t}$ is correlated with the regressors in equation (7), estimation of (7) will produce faulty inferences about $\mathrm{a}_{1}$ and the estimated properties of $u_{t}$.

The economic tracking portfolio approach to the same question is to regress the test asset on the tracking portfolio for news and control variables for expected returns. That is, the economic tracking portfolio analog to (7) is

$$
\mathrm{r}_{\mathrm{t}-1, \mathrm{t}}^{\mathrm{T}}=\mathrm{a}_{1} \mathrm{bR} \mathrm{R}_{\mathrm{t}-1, \mathrm{t}}+\mathrm{a}_{2} \mathrm{Z}_{\mathrm{t}-1}+\theta_{\mathrm{t}}
$$

where $b$ is defined by equation (5).

It turns out that the relation between these two approaches is simple: equation (8) is numerically identical to an instrumental variable estimation of equation (7), with the instruments 
being $\mathrm{R}_{\mathrm{t}-1, \mathrm{t}}$. Section 5 further discusses this relation and estimates instrumental variable regressions.

In equation (7), a good instrument is something that is both correlated with $\Delta \mathrm{E}_{\mathrm{t}}\left[\mathrm{y}_{\mathrm{t}+\mathrm{k}}\right]$ but uncorrelated with $\mathrm{v}_{\mathrm{t}}$. The tracking portfolio return satisfies the first criterion for a good instrument, since it is correlated with the desired object. It satisfies part of the second criterion, because it is uncorrelated with $\mathrm{e}_{\mathrm{t}, \mathrm{t}+\mathrm{k}}$. Unfortunately, the tracking portfolio return is not a perfect instrument because it is likely to be correlated with $\mathrm{u}_{\mathrm{t}}$. $\mathrm{bR}_{\mathrm{t}-1, \mathrm{t}}$ might be correlated with $\mathrm{u}_{\mathrm{t}}$ because both of these objects are derived from asset returns and might reflect common return variation that is unrelated to news about the target.

\section{Vector Autoregression Approach}

The third approach is pursued by Campbell in a series of papers (Campbell (1991), Campbell (1996), Campbell and Ammer (1993), and Campbell and Mei (1993)). Like the first approach, it uses innovations in contemporaneous variables to explain current asset returns. Like the second approach, it is interested in how changes in expectations about future economic variables affect asset returns. It uses the innovations from a vector autoregression (VAR) system to estimate changes in expected future variables, and uses the resulting estimated changes to explain asset returns.

Campbell uses a variety of current economic variables to explain asset returns. He uses both return and non-return forecasting variables (for target variables such as inflation, interest rates, labor income and future returns), and then tests whether innovations in these forecasting variables (from a VAR) are factors in asset returns. ${ }^{1}$

The VAR procedure for detecting loadings on the factors is mediated through a specific 
dynamic model of all the variables in the system. This requirement introduces a potential source of model misspecification. In contrast, the tracking portfolio approach lets the data choose loadings directly from regressions of future variables on returns, without having to rely on a complete description of the time series process generating the data .

\section{Data and summary statistics}

\section{$\underline{\text { Target variables and horizon }}$}

The targets $\left(\mathrm{y}_{\mathrm{t}+\mathrm{k}}\right)$ include seven macroeconomic variables suggested by theory and previous empirical work (such as Chen, Roll, and Ross (1986), Campbell and Ammer (1993), Campbell (1996), and Jagannathan and Wang (1996)). The seven target variables are: industrial production growth, real consumption growth, real labor income growth, inflation, excess stock returns, excess bond returns, and Treasury bill returns.

Industrial production is the change in the log of total production, seasonally adjusted. Consumption is the change in the log of real consumption of services and nondurable goods, seasonally adjusted. Labor income is the change in the log of personal income from wages and salaries, seasonally adjusted, minus CPI inflation. Inflation is the change in the log of the Consumer Price Index, not seasonally adjusted. Excess stock returns are continuously compounded returns on the CRSP value weighted aggregate portfolio minus continuously compounded returns on Treasury bills. Excess bond returns are continuously compounded returns on a portfolio of long-term government bonds minus continuously compounded returns on Treasury bills. Nominal Treasury bill returns are continuously compounded returns on Treasury bills. More details about the data are provided in the appendix. ${ }^{2}$

I construct tracking portfolios for news about annual changes in variables, using monthly 
data on the target variables and tracking future 12-month ahead changes in these variables. In the terms of the notation, period $\mathrm{t}$ is a month and $\mathrm{k}=12$. For example, future 12-month inflation in month $t$ is the inflation rate from the end of month $t$ to the end of month $t+12$. The forecasting regressions use monthly control variables and base asset returns from 1947:1 to 1994:12, and target variables from 1947:1 to 1995:12 (except for consumption, which starts in 1959:1).

\section{$\underline{\text { Base assets }}$}

The 13 base assets, $\mathrm{R}_{\mathrm{t}-1, \mathrm{t}}$, consist of four bond portfolios, eight industry-sorted stock portfolios, and the market portfolio for the stock market. All asset returns are in excess of the Tbill return. The four bond market portfolios are a portfolio of long-term government bonds, a portfolio of intermediate-term government bonds, a portfolio of one-year government bonds, and a portfolio of low-grade corporate bonds. The eight value-weighted industry portfolios consist of all stocks in CRSP sorted by SIC code: basic industries, capital goods, construction, consumer goods, energy, finance, transportation, and utilities. The eight industry classifications come from Sharpe (1982) and are defined in more detail in Table A. Last, the market (RMRF) is the CRSP NYSE/AMEX/NASDAQ value-weighted portfolio. ${ }^{3}$

These 13 portfolio returns are likely to be informative about future economic conditions. Industry portfolios are potentially useful because of obvious variations across industry in cyclicality, and because of evidence (see Boudoukh, Richardson, and Whitelaw (1994)) that this cyclicality is reflected in stock returns. Bond returns are likely to be useful since bond yields have also been shown to forecast future economic activity (see Stock and Watson (1989)). Last, the aggregate stock market has traditionally been used to forecast aggregate economic changes. 


\section{Control variables}

The lagged control variables, $\mathrm{Z}_{\mathrm{t}-1}$, include nine variables (plus a constant term). These nine variables are the Treasury bill return, a term premium for long-term government bonds (yield on long bonds minus Treasury bill yield), a term premium for one-year government notes (yield on one-year notes minus Treasury bill yield), a default premium for corporate bonds (BAA yield minus AAA yield), a default premium for commercial paper (commercial paper yield minus Treasury bill yield), the dividend yield on the CRSP value weight aggregate portfolio, and 12-month production growth, CPI inflation, and excess stock returns. It is important to note that the Treasury bill return in month $\mathrm{t}$ is a control variable, not a base asset, since the Treasury bill return in month $\mathrm{t}$ is known as of month $\mathrm{t}-1$.

The lagged control variables include the standard variables known to forecast returns on stocks and bonds. As a side effect, these Z's should also help forecast the target variable as well since the same variables that forecast returns also forecast economic activity (that is, $\mathrm{Z}_{\mathrm{t}-1}$ is correlated with $\left.\mathrm{E}_{\mathrm{t}-1}\left[\mathrm{y}_{\mathrm{t}+12}\right]\right)$.

Table 1 shows summary statistics for the variables $\mathrm{y}_{\mathrm{t}+12}, \mathrm{R}_{\mathrm{t}-1, \mathrm{t}}$, and $\mathrm{Z}_{\mathrm{t}-1}$. It also shows the correlation of these variables with $\mathrm{y}_{\mathrm{t}+12}$.

\section{Properties of Estimated Tracking Portfolios}

Table 2 shows the forecasting regressions that define the economic tracking portfolios for the seven target variables. Table 2 reports coefficients from OLS regressions of the 12-month ahead macroeconomic variables (from month $t$ to month $t+12$ ) on returns in month $t$ and lagged variables in month $\mathrm{t}-1$. The standard errors have been corrected for the overlapping dependent observations. ${ }^{4}$ Since the 13 base assets have returns that are highly collinear, the portfolio 
weights are not easy to interpret and have no particular meaning. More meaningful are the properties of the tracking portfolios shown in Table 3. Table 3 contains hypothesis tests and summary statistics for the tracking portfolio returns defined by the regressions of Table 2 .

\section{Do the tracking portfolios track their target variables?}

A crucial assumption for the use of tracking portfolios, in equation (1), is that returns reflect revisions in expectations about the target variable. Panel A of Table 3 reports p-values from tests of whether the returns forecast the target variable (the p-values are simply exclusion tests from the regressions presented in Table 2). The first row of Panel A reports tests of whether all 13 return series jointly forecast the target variables. The p-values reject the null of no forecasting ability, indicating that the returns are useful given the control variables in $\mathrm{Z}_{\mathrm{t}-1}$. This result verifies that innovations in returns are correlated with innovations in expectations about future variables, so that it is feasible to track all seven target variables using the base assets.

The other rows of Panel A test whether three subsets of returns forecast the target variable (given the other returns): the 12 returns excluding the market portfolio, the eight industry portfolios, and the four bond portfolios. For example, the second row shows that for all seven variables, forecasting power is not limited to just the aggregate stock market. In general, both bonds and stocks contribute tracking power.

\section{Tracking ability}

Panel A shows that the tracking portfolios do track. How well do the tracking portfolios track? They are designed to track news, so to evaluating the tracking power, what we would like to do is run a regression of news on unexpected returns $\left(\Delta \mathrm{E}_{\mathrm{t}}\left[\mathrm{y}_{\mathrm{t}+\mathrm{k}}\right]\right.$ on $\left.\tilde{\mathrm{r}}_{\mathrm{t}-1, \mathrm{t}}\right)$, and see if the R- 
squared is high. Unfortunately, the answer to this question is unknowable, since we do not observe $\Delta \mathrm{E}_{\mathrm{t}}\left[\mathrm{y}_{\mathrm{t}+\mathrm{k}}\right]$.

One can calculate a partial R-squared that gives a lower bound on the percent of the variance of news that is captured by tracking portfolio returns. Specifically, one runs a regression of $\mathrm{y}_{\mathrm{t}+\mathrm{k}}-\mathrm{E}\left[\mathrm{y}_{\mathrm{t}+\mathrm{k}} \mid \mathrm{Z}_{\mathrm{t}-1}\right]$ on $\mathrm{bR}_{\mathrm{t}-1, \mathrm{t}}-\mathrm{E}\left[\mathrm{bR} \mathrm{R}_{\mathrm{t}-1, \mathrm{t}} \mid \mathrm{Z}_{\mathrm{t}-1}\right]$, which in the notation is the same as running a regression with $\mu_{\mathrm{t}-1}+\Delta \mathrm{E}_{\mathrm{t}}\left[\mathrm{y}_{\mathrm{t}+\mathrm{k}}\right]+\mathrm{e}_{\mathrm{t}, \mathrm{t}+\mathrm{k}}$ on the left hand side and $\tilde{\mathrm{r}}_{\mathrm{t}-1, \mathrm{t}}$ on the right hand side. The R-squared in this regression is lower bound for the R-squared in a regression of $\Delta \mathrm{E}_{\mathrm{t}}\left[\mathrm{y}_{\mathrm{t}+\mathrm{k}}\right]$ on $\tilde{\mathrm{r}}_{\mathrm{t}-1, \mathrm{t}}$. Panel $\mathrm{B}$ of Table 3 shows this partial R-squared. The lower bound ranges from 0.04 to 0.23 .

\section{$\underline{\text { Risk premia on tracking portfolios }}$}

Panel C of Table 3 shows mean excess returns for the tracking portfolios. The numerical magnitude of these risk premia show the price of one unit of exposure to $\Delta \mathrm{E}_{\mathrm{t}}\left[\mathrm{y}_{\mathrm{t}+\mathrm{k}}\right]$. Panel $\mathrm{C}$ also shows the standard deviation of these portfolio returns, and the t-test for the hypothesis that the mean return is zero. ${ }^{5}$

The production, consumption, and labor income portfolios have risk premia which are positive and significantly different from zero. Chen, Roll, and Ross (1986) also find positive risk premia for stocks with returns that move with production. The positive risk premia is one measure of the cost of business cycles: investors demand high returns on assets exposed to macroeconomic fluctuations.

The inflation and T-bill portfolios have risk premia which are negative but insignificantly different from zero. Chen, Roll, and Ross also find a negative risk premia for stocks with returns 
that covary with inflation.

For future stock and bond returns, the theoretical sign is ambiguous and depends on risk aversion (see for example Campbell 1996). Panel C shows that both future stock and bond return portfolios earn negative returns, suggestive (loosely) of a coefficient of relative risk aversion that is less than one. However, these negative returns are insignificantly different from zero.

\section{Market model regressions}

The market model regressions in Panel D of Table 3 evaluate the ability of the CAPM to explain the risk premia on tracking portfolios. Before discussing the results, a statistical fact: since the tracking portfolios are linear combinations of the base assets, the $\alpha$ 's of the tracking portfolios are linear combination of the $\alpha$ 's of the base assets. In other words, the CAPM can only misprice the tracking portfolio if it also misprices one or more of the 13 base assets.

Only the consumption portfolio has an $\alpha$ that is significantly different from zero. The primary reason for the consumption portfolio's mispricing by the CAPM is that returns on one of the base assets (the one-year treasury bond portfolio) is also mispriced by the CAPM. Removal of this portfolio from the set of base assets results in an insignificant $\alpha$ for consumption. ${ }^{6}$

\section{The correlation of tracking portfolio returns: Economic interpretation}

Panel E shows correlations of the seven tracking portfolio returns with each other, as well as correlations of the tracking portfolios with the base assets. This subsection makes a few comments about these correlations, and the next subsection discusses them further.

Economists often test hypotheses about the predictive power of aggregate stock returns for various economic variables. For example, Stock and Watson (1989) find that given other 
forecasting variables, aggregate stock returns do not help predict future economic activity. The correlation of aggregate stock returns (RMRF) with tracking portfolios in Panel E show how different the market portfolio is from the optimal portfolio for forecasting future economic activity. Tracking portfolios might perform better than aggregate stock returns because they hedge out portions of aggregate return variation that are unrelated to future production (such as changes in taxes, liquidity, or sentiment). For example, Panel E shows that the correlation of the production tracking portfolio and the market portfolio is 0.57 , so that the market portfolio is far from being the optimal predictive portfolio for production.

Panel E also shows the production portfolio is positively correlated with the inflation portfolio, suggesting that innovations to output are positively correlated with innovations to inflation. This correlation is evidence in favor of an upward sloping Phillips-curve. As shown in Table 1, this positive correlation is not present in realizations of inflation and production, suggesting that tracking portfolios are able to disentangle the different effects of unexpected and expected components.

\section{The correlation of tracking portfolio returns: Comparison to VAR approach}

Table 4 compares the correlations of the tracking portfolios with the analogous results from Campbell and Ammer (1993). Panel A reprints their table showing correlations of innovations to different variables. They construct these innovations using a first-order monthly VAR.

Panel B of Table 4 shows the corresponding results using the economic tracking portfolios approach, both for the full sample and for Campbell and Ammer's sample of 1952:11987:2. It shows the correlations of unexpected returns on different tracking portfolios. The 
unexpected returns, $\tilde{\mathrm{r}}_{\mathrm{t}-1, \mathrm{t}}$ are calculated as the residual in the projection equation:

$$
\hat{\mathrm{bR}}_{\mathrm{t}-1, \mathrm{t}}=a \mathrm{Z}_{\mathrm{t}-1}+\tilde{\mathrm{r}}_{\mathrm{t}-1, \mathrm{t}}
$$

Campbell and Ammer examine innovations in real future short-term interest rates, so Panel B transforms the tracking portfolio for nominal T-bill returns into a tracking portfolio for real T-bill returns by subtracting the inflation portfolio return (since the portfolio weights are linear, one can add and subtract returns in this way).

Since Campbell and Ammer's variables are innovations to the weighted sum of the realizations of the variable into the infinite future, and tracking portfolio innovations are merely for the next 12 months, these tables are conceptually (as well as methodologically) different. Nevertheless, Table 4 shows the results are quite similar. The similarity is striking since the tracking portfolios rely on a fairly different set of econometric assumptions.

For example, news about future inflation and news about future expected stock returns are negatively correlated (the correlation is -0.65 for Campbell and Ammer (1993) and -0.58 for the tracking portfolio approach using the same sample period). Another example is that innovations in expected stock returns and expected bond returns are positively correlated (the correlation is 0.82 for Campbell and Ammer (1993) and 0.58 for the tracking portfolio approach). This result suggests that risk premia on stocks and bonds move together over time.

\section{Examining the implied forecasts}

Figures 1-3 show the time series of the cumulative innovations in returns on the production, inflation, and stock return portfolios from 1947 to 1994 . These figures cumulate unexpected returns on the tracking portfolio ( $\tilde{\mathrm{r}}_{\mathrm{t}-1, \mathrm{t}}$ from equation (9)). By cumulating, the 
intention is to approximately display $\mathrm{E}_{\mathrm{t}}\left[\mathrm{y}_{\mathrm{t}+\mathrm{k}}\right]$. Since the series are based on regression residuals, by construction they always begin and end at zero.

The figures also show actual growth rates of the target variable from month t-12 to month t. If tracking portfolios are working well, one should see the tracking portfolio return predict subsequent moves in the target variable.

Since the tracking portfolios have been chosen in-sample to forecast the 12-month ahead target variable, it is no surprise that one can see some of this forecasting ability in the figures. Figure 1 shows the recession of 1990-1991. The recession started in August 1990; the production tracking portfolio peaked 12 months earlier (as it should), in August 1989. Figure 2 shows that inflation tracking portfolio was forecasting greatly increased inflation during the 1973 and 1979 oil shocks. Figure 3 shows that the stock return tracking portfolio falls sharply in the first half of 1987, right before the October 1987 crash.

\section{Estimating the reaction of prices to news using instrumental variables}

Tables 5-7 use tracking portfolios to test hypotheses about the reaction of aggregate stock prices to news, the reaction of bond prices to news, and the reaction of small stock prices to news. In each case, a test asset return is on the left-hand side of the regression and tracking portfolio returns (along with lagged control variables) are on the right-hand side. As mentioned in section 2, a regression of current test asset returns on $\hat{b}_{t-1, t}$ and $\mathrm{Z}_{\mathrm{t}-1}$ is identical to an instrumental variables regression of current test asset returns on future target variables $\mathrm{y}_{\mathrm{t}+\mathrm{k}}$ and $\mathrm{Z}_{\mathrm{t}-1}$ on the right-hand side, and current base assets returns and $\mathrm{Z}_{\mathrm{t}-1}$ as instruments. ${ }^{7}$ As usual, the inclusion of $\mathrm{Z}_{\mathrm{t}-1}$ is meant to control for expected returns.

If the returns from the tracking portfolios are correlated with the residuals in the desired 
equation (equation (6)), then the tracking portfolio will not be a valid instrument. While it is impossible to eliminate this potential source of bias, Tables 5-7 attempt to mitigate it by using tracking portfolios constructed using a set of base assets that do not include the test asset on the left-hand side.

Stock prices and future economic activity

Table 5 runs regressions of current stock returns on future industrial production growth. Table 5 puts stock returns on the left-hand side of the regression, so in constructing the tracking portfolio returns on the right-hand side of the regression, only the four bond returns are used. More information about these tracking portfolios with restricted base assets is given later, in Table 9.

The first two regressions show useful benchmarks for explanatory power. The first regression shows that the control variables alone have an R-squared of 0.08 . Since the tracking portfolio for production is constructed only using bond returns, the second regression shows the ability of long bond returns to explain stock returns. Together with the control variables, the Rsquared is 0.14. The low R-squared is similar to results from Fama and French (1993), who find that bond market returns have little ability to explain stock market returns.

The third regression uses realized production as a right hand side variable in an OLS regression, and the fourth regression shows instrumental variable estimation of the same regression. The two statistics of interest are the coefficient on production and the R-squared.

First, compare the coefficient on production in the two regressions. The OLS regression shows that future production does indeed help explain this month's stock return, with a positive and significant coefficient. The coefficient of 0.10 is similar in magnitude to the coefficients 
estimated by Fama (1990), and implies that news that production growth will be one percent higher over the next year results in a tenth of a percent increase in aggregate stock prices today. In the instrumental variables regression, the coefficient rises by an order of magnitude, so that news that production growth will be one percent higher over the next year results in a 2.77 percent in aggregate stock prices today.

Second, compare the R-squareds. Fama (1990) uses the OLS R-squareds in similar regression as a measure of market rationality. The R-squared rises from 0.09 using realized production to 0.25 using the production tracking portfolios.

The last regression in Table 5 is a single factor model where aggregate stock returns have a 2.77 loading on the bond-only production tracking portfolio. The regression makes a statistical statement with an economic interpretation. The statistical statement is that bond returns explain some of the variation in stock returns. The economic interpretation is that bond returns explain stock returns because both are exposed to news about future production. The tracking portfolio procedure imposes discipline. ${ }^{8}$ Compared to an unrestricted regression of aggregate stock returns on the four bond portfolio returns, the tracking portfolio imposes the restriction that the portfolios can only enter the regression in a specific linear combination.

What is the cost of this restriction, in terms of explanatory power? Answering this question serves two purposes. First, it provides a statistical evaluation of how much of the common variation in asset returns is captured by the production factor. In this context, the common variation is between four bond portfolios on the one hand, and the aggregate stock portfolio on the other. Second, it provides an answer to the economic question of whether bond returns help explain aggregate stock returns only because of their common exposure to 
production news.

Substituting the four bond returns for the production tracking portfolio returns results in an R-squared that rises from 0.25 to 0.31 , so that 0.06 is the cost of imposing the restriction that four bond portfolios have the weights given by the production tracking portfolio. However, this increase in R-squared is statistically insignificant. ${ }^{9}$ Thus one cannot reject the hypothesis that the only reason that bond returns explain stock returns is because both reflect news about future production.

\section{Bond prices, future interest rates, and future risk premia}

Table 6 uses tracking portfolios to explain movements in aggregate bond prices. Bond prices should covary negatively with news about future excess returns on bonds and future nominal risk free interest rates.

Table 6 puts bond returns on the left-hand side of the regression, so in constructing the tracking portfolio returns on the right-hand side of the regression, only the nine stock returns are used. The first regression shows control variables alone, and the second uses contemporaneous stock market excess returns to explain returns on long-term government bonds.

The third regression shows OLS estimation where realized future Treasury bill returns and excess returns on long-term government bonds are placed on the right-hand side of the regression. The coefficients are both negative (as expected) and statistically significant.

The last regression shows instrumental variables estimation using the excess bond return and nominal T-bill return tracking portfolios. These tracking portfolios are constructed using only the nine stock return portfolios. Again, the coefficients all rise substantially.

The last regression in Table 6 is a two factor model where long bonds have a -0.62 
loading on the (stock-only) bond risk premia factor, and a -5.89 loading on the (stock-only) riskfree rate factor. Looking again at the cost of imposing the restriction that the nine stock portfolios have weights given by the tracking portfolios, the R-squared rises from 0.20 in the restricted regression to 0.31 in an unrestricted regression. In this case, the increase in R-squared is significant, so that stock returns do not explain bond returns only because of common exposure to year-ahead risk premia and interest rates. This diagnostic indicates that the two factor model in Table 6 fails to capture common variation in asset returns, and that one needs to find other economic variables in order to understand the covariation of returns.

\section{The cyclicality of small stocks}

Table 7 tests the hypothesis that small stocks have returns that are more cyclical than large stocks, beyond the fact that small stocks have higher market $\beta$ 's. This is an interesting hypothesis to test because of other evidence that small firms are more exposed to aggregate fluctuations (see Lamont, Polk, and Saá-Requejo, 1999 for evidence and a review of this literature). The small stock portfolio consists of firms in the smallest size quintile.

The dependent variable in Table 7 is excess returns on the small stock portfolio; the second regression shows that small stocks have market $\beta$ 's that are above one. The third regression puts future production on the right-hand side, controlling for the current market return. By controlling for the market return, one is using the market's sensitivity to future production as a benchmark. The coefficient on future production will be positive if small stocks have a higher sensitivity to production news than the market has. The coefficient on future production is insignificant: using realized production growth, one cannot reject the hypothesis that small stocks are not more cyclical than predicted by their high market $\beta$ 's. 
The last regression instruments for future production growth using the thirteen base asset returns, and shows that the coefficient on future production rises and becomes significant. The last regression says that news that production growth will be one percent higher than expected causes prices on small stocks to rise about one percent more than predicted by the market model.

The last regression of Table 7 is a two factor model where small stock returns have a 0.99 loading on the market factor and a 1.14 loading on the industrial production factor. Going from this regression to an unrestricted regression with all 13 returns on the right-hand side, the Rsquared increases from 0.76 to 0.82 . This increase is statistically insignificant, so that one cannot reject the idea that industry returns and bond returns explain small stock returns only through exposure to news about future industrial production (and through loadings on the market factor).

In summary, using tracking portfolios to measure news results in a substantial rise in the estimated magnitude of the reaction of prices to news. Tables 5-7 are simultaneously instrumental variables estimates about reaction to fundamental news, and factor models which explain common variation in returns. As instrumental variables estimation, Tables 5-7 are not perfect, since the coefficients are subject to bias. As factor models, Tables 5-7 are an improvement over less structured estimation, because they have economic meaning.

\section{$\underline{\text { 6. Robustness Tests }}$}

\section{$\underline{\text { Rolling regressions }}$}

Table 8 uses rolling regressions to examine the out-of-sample performance of tracking portfolios. Panel A shows regressions generated using a twenty-year estimation window. Panel B uses a five-year estimation window. Five-year estimation periods for covariances are 
traditional in finance, although one might wonder if this period is long enough when estimating covariances with economic variables such as output or inflation.

The tracking portfolios in Panel A are generated as follows. Every month, one runs the tracking portfolio regression using only historical data, up to and including this month's realization of the target variable. In month $\mathrm{t}$, one estimates $\hat{b}_{\mathrm{t}}$ and $\hat{c}_{t}$ using the past 20 years of monthly data. This procedure is repeated every month, and the result are two times series: $\hat{\mathrm{b}}_{\mathrm{t}} \mathrm{R}_{\mathrm{t}-1, \mathrm{t}}$ and $\hat{c}_{t} \mathrm{Z}_{\mathrm{t}-1 .} \hat{\mathrm{b}}_{\mathrm{t}} \mathrm{R}_{\mathrm{t}-1, \mathrm{t}}$ is the return from a dynamic portfolio strategy following a welldefined trading rule that is a function only of observable data.

Using these two forecast components, Table 8 reports regressions of $y_{t+12}$ on $\hat{b}_{t} R_{t-1, t}$ and $\hat{c}_{t} \mathrm{Z}_{\mathrm{t}-1}$. The coefficient on $\hat{\mathrm{b}}_{\mathrm{t}} \mathrm{R}_{\mathrm{t}-1, \mathrm{t}}$ in these OLS time-series regressions is a measure of how well the tracking portfolios tracks out-of-sample. If the tracking portfolio generated using the rolling procedure were perfect, then the coefficient would be one. If the tracking portfolio were useless, the coefficient would be zero. In general, one would expect a coefficient of less than one because of error in coefficient estimates, and possibly because of changing true parameter values as well. The issue is similar to the shrinkage of CAPM $\beta$ 's.

Panel A of Table 8 shows that using a twenty-year estimation window, tracking portfolios demonstrate an ability to track the target variable out-of-sample, since the coefficient is in all seven cases significantly different from zero. The coefficients range from 0.37 to 0.73 . Forecasting deterioration is not limited to tracking portfolios. The coefficients on $\hat{c}_{t} \mathrm{Z}_{\mathrm{t}-1}$ range between 0.27 and 1.03, indicating that non-return variables also are not perfect out-of-sample. Panel B shows that out-of-sample performance using a five-year estimating window is Economic Tracking Portfolios - Page 25 
disastrous. None of the coefficients on $\hat{b}_{t} R_{t-1, t}$ are above 0.26 or close to significant. The coefficients on $\hat{c}_{t} \mathrm{Z}_{\mathrm{t}-1}$ are also dramatically worse in the five-year case. In short, a five-year sample period is not a good idea when tracking macroeconomic variables, or in trying to capture to covariance of asset returns with innovations to macroeconomic expectations.

In summary, tracking portfolios do track out-of-sample (using a sensible estimation period). Tracking portfolios are a feasible way for investors to hedge economic risk in real time, although investors should take into account the predictable out-of-sample deterioration. Alternative horizons for target variables and base assets

Table 9 shows various alternative ways of constructing tracking portfolios. Panel A reprints relevant statistics from Table 3. Panels B-F each show a different variation on the baseline specification of Table 2 .

The table shows three sets of facts about the differently constructed tracking portfolio. First, it tests whether the tracking portfolios track: it shows p-values from exclusion tests in the forecasting regression, which evaluate whether the returns have forecasting ability. Second, it shows the partial R-squared of the target variable on tracking returns. Third, it shows the correlation of the baseline tracking portfolios with the tracking portfolio constructed using the various different methods.

Panel B shows results using a five-year target variable instead of one-year target variable. The first row shows that the tracking portfolios do track. The second row shows that the partial R-squared is generally lower than in Panel A. This fact is unsurprising since only a smaller percentage of news about the next five years is released in any given month. The last row shows that the correlations with the baseline tracking portfolios are moderately high, ranging from 0.27 
to 0.84 .

Panel C shows results using quarterly base asset returns instead of monthly base asset returns. These regressions continue to use monthly observations, but they use returns $\mathrm{R}_{\mathrm{t}-3, \mathrm{t}}$ and control variables $\mathrm{Z}_{\mathrm{t}-3}$. Again, quarterly tracking portfolios do track. Not surprisingly, the partial R-squared's rise, since more information is released in three months than in one. The correlations with baseline portfolios are calculated using monthly returns, where the portfolio weights come from the regression using quarterly returns. The correlations are very high (0.91 to 0.97$)$, indicating that it is essentially irrelevant whether one calculates portfolio weights using monthly or quarterly regressions.

\section{Restricting the base assets}

Panels D and E show tracking portfolio returns constructed with subsets of the 13 base assets, $\mathrm{R}_{\mathrm{t}-1, \mathrm{t}}$. Panel D uses only the nine stock portfolios, and Panel E uses only the four bond portfolios. These are the same portfolios used in Tables 5 and 6.

With the exception of the stock-only consumption tracking portfolio, the p-values in Panels D and E show that one can track the target variables with either bond returns or stock returns. Except for the nominal T-bill tracking portfolio, the correlations with baseline are higher for the stock-only tracking portfolios $(0.70-0.94)$ than for the bond-only portfolios $(0.43$ 0.83), indicating that the baseline portfolios are more influenced by stock returns than bond returns.

\section{Restricting the control variables}

Panel F shows results with no control variables, so that the right-hand side of the regression contains a constant term and 13 base asset returns. These regressions are surely 
misspecified, but they give a sense of the importance of the control variables. With the exception of the inflation tracking portfolio, the tracking portfolios still track.

For the nominal T-bill return, the baseline portfolio correlation is near zero, suggesting that control variables are a very important ingredient in constructing its tracking portfolio. Nominal T-bill returns over the next year are very predictable (as shown by the R-squared of 0.91 in Table 2). Thus excluding lagged control variables, such as the lagged T-bill return, makes a dramatic difference in the properties of the tracking portfolio.

For the other six tracking portfolios, the baseline portfolio correlations are fairly high, ranging from 0.63 to 0.89 . For these tracking portfolios, then, control variables are not as important.

\section{Other potential base assets}

The analysis so far has used 13 base assets in constructing tracking portfolios. Table 10 examines three additional stock portfolios which might potentially be useful in tracking economic variables. One could imagine adding other interesting portfolios such as gold, real estate, and international securities, but these extensions are beyond the scope of this paper. ${ }^{10}$

Table 10 shows two facts about the candidate portfolios. First, it shows whether the candidate portfolio adds forecasting ability in the presence of the 13 base asset returns. This test corresponds to the p-value for the hypothesis that the candidate can be excluded from the baseline regression. Second, Table 10 shows the correlation of the candidate portfolio with the tracking portfolios.

The three portfolios are the value factor, the size factor, and the momentum factor. The value and size factors were both originally constructed by Fama and French (1993), and are 
available 1947:1-1994:12 from Davis, Fama and French (1999). The momentum factor is available 1963:7-1994:12 from Carhart (1997).

The value factor is HML, and measures stock returns related to the book-to-market ratio. HML (high minus low) is constructed by subtracting a low book-to-market portfolio return from a high book-to-market portfolio return. The size factor is SMB (small minus big), and measures return variation related to firm size. SMB is constructed by subtracting a large firm portfolio return from a small firm portfolio return (size is measured by market capitalization). The momentum factor is PR1YR (prior one-year return), and measures return variation related to past price momentum. PR1YR is constructed by subtracting returns from a portfolio of losers (firms with low returns in the past year) from a portfolio of winners (firms with high returns in the past year).

First, Table 10 shows that in general the three candidate portfolios do not help track the target variables, so that excluding them from the baseline specification is appropriate. There are 21 different p-values in Table 10, and only one of them (the test for whether the size factor helps forecast inflation) is significant at the 5\% level. One out of 21 is the expected number due to random chance.

Second, Table 10 shows that the three candidate portfolios are not particularly highly correlated with any of the tracking portfolios. The highest is the 0.33 correlation between the size factor and the production tracking portfolio. This correlation is consistent with results from Table 7: small stocks load heavily on the production tracking portfolio.

\section{Summary of robustness results}

In general, the results of this section suggest that the portfolios estimated in Table 2 are 
robust to different specifications. The baseline portfolios are not very different from portfolios constructed using alternative methods. Some changes (such as using 3-month returns on base assets or dropping all bonds from the base assets) make virtually no difference in most cases. Value, size, and momentum are not particularly related to or useful for tracking economic variables.

\section{Conclusions}

\section{Summary of the results}

Using post-war US data, it is possible to track expectations about future economic variables using stocks from different industries and bonds of different maturities and qualities. These tracking portfolios do not merely reflect the aggregate stock market or aggregate bond market, but instead combine the different returns optimally. Out-of-sample results suggest that going into the future, tracking portfolios will be useful in forecasting and hedging macroeconomic variables.

The properties of the tracking portfolio returns shed light on a variety of hypotheses about the relationship between returns and economic variables. In general, the results using tracking portfolios are quite similar to conclusions based on VAR methods of estimating innovations using non-return variables. In contrast, the results using tracking portfolios are quite different from regressing returns on realizations of future variables. Using returns as instrumental variables results in a much higher estimated sensitivity of asset prices to news about future economic variables, compared to previous results.

The instrumental variable results are an example of a factor model where one regresses returns on the left-hand side against returns on the right-hand side. In this case, however, the 
coefficients have an economic interpretation. Using tracking portfolios imposes discipline: asset returns are only allowed to go on the right-hand side of the regression if they contain information about economic variables.

\section{$\underline{\text { Extensions }}$}

One could also construct tracking portfolios using daily returns. This would allow one to estimate daily updates on what financial markets think about future inflation, economic activity, and expected returns, and to examine specific episodes. E.g., when the Fed announces it is tightening monetary policy, do the inflation and output forecasting portfolios fall?

Forming daily tracking portfolios could also address a long-standing puzzle. Bond prices react dramatically to macroeconomic announcements, but aggregate stock prices typically do not (e.g. McQueen and Roley (1993)). It could be that stock prices do not react because competing effects on future discount rates and cash flows cancel out in aggregate. It is possible to investigate this explanation using tracking portfolios. In this respect, tracking portfolios have an inherent advantage over monthly VAR's using non-return variables.

Economic Tracking Portfolios - Page 31 


\section{APPENDIX: Data sources.}

\section{Target variables}

Industrial production is provided by the Federal Reserve. Consumption is provided by DRI Basic Economics (formerly Citibase), and using the variable names is equal to GMCQGMCDQ. Labor income is provided by DRI Basic Economics, variable name GMW. The CPI index, the CRSP value weighted aggregate portfolio returns, the Treasury bill portfolio return, and the long-term government bond portfolio returns are all provided by Ibbotson Associates. Base assets

The eight industry portfolio returns are calculated by the author using data provided by CRSP. The four bond portfolio returns are provided by Ibbotson Associates.

\section{Control variables}

The long bond yield, one-year yield, and commercial paper yield are provided by Ibbotson Associates. The T-bill yield, BAA yield, and AAA yield are provided by DRI Basic Economics, variable names FYGM3T, FYBAAC, and FYAAAC. The dividend yield is constructed using the total and capital gains-only returns on CRSP value weight aggregate portfolio, provided by Ibbotson Associates.

\section{Other variables}

HML and SMB are provided by Eugene Fama. PR1YR is provided by Mark Carhart. I thank these two individuals for graciously providing their data. Small stock returns are provided by Ibbotson Associates. 


\section{FOOTNOTES}

${ }^{1}$ Both Campbell's papers and this paper assume that the coefficients do not change over time. An alternative would be to allow for conditional coefficients, as in Ferson and Harvey (1991).

${ }^{2}$ Ideally, one would like to use seasonally unadjusted data since the seasonal adjustment procedures can distort the properties of time-series data. Unfortunately, monthly labor income and personal nondurable consumption are not published in unadjusted form.

${ }^{3}$ The eight industry portfolios, value weighted, aggregate to the market. However, the weights are time-varying since each industry contains a changing fraction of total market value. Thus the market portfolio and the eight industries are not exactly collinear, though of course they are very highly correlated.

${ }^{4}$ The standard errors are calculated using Newey-West with 24 lags. The exact correction would be Hansen-Hodrick with 12 lags, but this covariance matrix was not convenient to use since it resulted in undefined test statistics for some of the tests performed in this paper.

${ }^{5}$ The reported standard deviation is the usual time-series standard deviation, taken $\hat{b}$ as given (so that one can generate the in-sample Sharpe ratio by taking the ratio of the mean and standard deviation). The t-statistic, in contrast, is calculated using GMM, and takes into account the estimation error of $\hat{b}$.

${ }^{6}$ In comparing the consumption portfolio to the other tracking portfolios, it is also important to note that the consumption portfolio reflects a shorter sample period than the other portfolios. 
${ }^{7}$ The explanatory power and the coefficients on the macroeconomic variables/tracking variables are numerically identical. The coefficients on $\mathrm{Z}_{\mathrm{t}-1}$ correspond to $\delta$ in the regression $\mathrm{r}_{\mathrm{t}-1, \mathrm{t}}^{\mathrm{T}}=\delta \mathrm{Z}_{\mathrm{t}-1}+\phi\left(\mathrm{bR}_{\mathrm{t}-1, \mathrm{t}}+\mathrm{cZ}_{\mathrm{t}-1)}\right)+\mathrm{v}_{\mathrm{t}, \mathrm{t}+12}$. Also, as is usual in instrumental variable regressions, the standard errors in Tables 5-7 have been corrected to reflect for the imprecision of the first-stage regression.

${ }^{8}$ Dumas (1994) uses a similar disciplined approach to finding variables that predict returns. To avoid data mining, he predicts returns using only those variables that predict future economic activity.

${ }^{9}$ The p-value for the hypothesis that the portfolio weights are different from the tracking portfolio weights is 0.12 . This test is carried out by adding three of the bond returns to the right-hand side of the instrumental variables regression, and running an exclusion test for the three bond returns. One can also not reject the hypothesis that the industrial production tracking portfolio has a zero coefficient (the coefficient is 2.92 and the tstatistic is 1.20) in this regression, so the tests are fairly uninformative.

${ }^{10}$ Titman and Warga (1989) examine real estate returns and inflation forecasts. 


\section{REFERENCES}

Boudoukh, Jacob, Matthew Richardson, and Robert F. Whitelaw, 1994, Industry returns and the Fisher effect, Journal of Finance 49, 1595-1616.

Breeden, Douglas T., 1979, An intertemporal asset pricing model with stochastic consumption and investment opportunities, Journal of Financial Economics 7, 265-296.

Breeden, Douglas T., Michael R. Gibbons, and Robert Litzenberger, 1989, Empirical tests of the consumption-oriented CAPM, Journal of Finance 44, 231-262.

Campbell, John Y., 1991, A variance decomposition for stock returns, Economic Journal 101, 157-179.

Campbell, John Y., 1996, Understanding risk and return, Journal of Political Economy 104, 267297.

Campbell, John Y., and John Ammer, 1993, What moves the stock and bond markets? A variance decomposition for long-term asset returns, Journal of Finance 48, 3-38.

Campbell, John Y., and Jianping Mei, 1993, Where do betas come from? Asset price dynamics and the sources of systematic risk, Review of Financial Studies 6, 567-592.

Carhart, M.M., 1997, "On the persistence of mutual fund performance," Journal of Finance, 52, 57-82.

Chan, Louis K.C., Jason Karceski and Josef Lakonishok, 1998, The risk and return from factors, Journal of Financial and Quantitative Analysis 33, 159-188.

Chen, Nai-Fu, Richard Roll, and Stephen A. Ross, 1986, Economic forces and the stock market, Journal of Business 59, 383-403.

Davis, James, Eugene F. Fama and Kenneth R. French, 1999, Characteristics, covariances, and average returns: 1929-1997, February 1999, Center for Research in Security Prices Working Paper 471.

Davis, Steven J., and Paul Willen, 1998, "Using financial assets to hedge labor income risks: Estimating the benefits," University of Chicago working paper.

Dumas, Bernard, 1994, A test of the international CAPM using business cycle indicators as instrumental variables, in Jeffrey Frankel, ed.: The Internationalization of Equity Markets (University of Chicago Press, Chicago, Ill.). 
Fama, Eugene F., 1981, Stock returns, real activity, inflation, and money, American Economic Review 71, 545-565.

Fama, Eugene F., 1990, Stock returns, expected returns, and real activity, Journal of Finance 45, 1089-1108.

Fama, Eugene F. and Kenneth R. French, 1993, Common risk factors in the returns on stocks and bonds, Journal of Financial Economics 33, 3-56.

Ferson, Wayne E. and Campbell R. Harvey, 1991, The variation of economic risk premiums, Journal of Political Economy 99, 385-415.

Jagannathan, Ravi and Wang, Zhenyu, 1996, The conditional CAPM and the cross-section of expected returns, Journal of Finance 51, 3-53.

Lamont, Owen, Christopher Polk and Jesús Saá-Requejo, 1999, Financial constraints and stock returns, working paper.

McQueen, Grant and V. Vance Roley, 1993, Stock prices, news, and business conditions, Review of Financial Studies 6, 683-707.

Schwert, G. William, 1990, Stock returns and real activity: A century of evidence, Journal of Finance 45, 1237-1257.

Sharpe, William F., 1982, Factors in New York Stock Exchange Security Returns, 1931-1979, Journal of Portfolio Management Fall 1982.

Shiller, Robert J., 1993, Macro markets (Oxford University Press, Oxford, UK).

Shiller, Robert J., and Stefano Athanasoulis, 1995, World income components: Measuring and exploiting international risk sharing opportunities, NBER Working Paper No. 5095

Stock, James, and Mark W. Watson, 1989, New indexes of coincident and leading economic indicators, in Blanchard, Olivier Jean Blanchard and Stanley Fischer, eds: NBER Macroeconomics Annual 1989 (University of Chicago Press, Chicago).

Titman, Sheridan and Arthur Warga, 1989, Stock returns as predictors of interest rates and inflation, Journal of Financial and Quantitative Analysis 24, 47-57. 
Table 1: Summary Statistics for Target Variables, Control Variables, and Base Asset Returns, 1947:1-1994:12

\begin{tabular}{|c|c|c|c|c|c|c|c|c|c|c|}
\hline & & Mean & Std dev & $\begin{array}{l}\text { Production } \\
\text { growth }_{\mathrm{t} t+12}\end{array}$ & $\begin{array}{l}\text { Consumption } \\
\text { growth }_{\mathrm{t} t+12}\end{array}$ & $\begin{array}{l}\text { Labor income } \\
\text { growth }_{\text {t.t+12 }}\end{array}$ & Inflation $_{\mathrm{t}, \mathrm{t}+12}$ & $\begin{array}{l}\text { Excess stock } \\
\text { returns } \mathrm{s}_{\mathrm{t}, \mathrm{t}+12}\end{array}$ & $\begin{array}{l}\text { Excess bond } \\
\text { returns } \mathrm{s}_{\mathrm{t},+12}\end{array}$ & \begin{tabular}{|l|} 
Nom. T-bill \\
returns
\end{tabular} \\
\hline & Production $_{\mathrm{t}, \mathrm{t}+12}$ & 3.46 & 6.07 & \multicolumn{7}{|c|}{ Correlation } \\
\hline \multirow{5}{*}{ y } & Consumption $_{\mathrm{t}, \mathrm{t}+12}$ & 3.14 & 1.62 & 0.68 & 1.00 & & & & & \\
\hline & Labor income $_{t, t+12}$ & 2.93 & 3.30 & 0.86 & 0.82 & 1.00 & & & & \\
\hline & Inflation $_{t, t+12}$ & 4.00 & 3.11 & -0.20 & -0.47 & -0.41 & 1.00 & & & \\
\hline & Excess stock returns $_{\mathrm{t}, t+12}$ & 6.57 & 15.11 & 0.24 & 0.25 & 0.26 & -0.35 & 1.00 & & \\
\hline & Excess bond returns $\mathrm{t}_{\mathrm{t}, \mathrm{t}+12}$ & 0.36 & 9.26 & -0.22 & 0.04 & -0.09 & -0.38 & 0.33 & 1.00 & \\
\hline & Nom.T-bill returns $_{\mathrm{t}, \mathrm{t}+12}$ & 4.81 & 2.93 & -0.29 & -0.44 & -0.42 & 0.64 & -0.32 & -0.09 & 1.00 \\
\hline \multirow{13}{*}{$\mathrm{R}$} & RMRF $_{\mathrm{t}-1, \mathrm{t}}$ (market) & 0.61 & 4.14 & 0.22 & 0.13 & 0.20 & -0.08 & 0.01 & -0.11 & -0.08 \\
\hline & BASIC INDS $_{\mathrm{t}-1, \mathrm{t}}$ & 0.58 & 4.89 & 0.19 & 0.08 & 0.16 & -0.02 & -0.03 & -0.17 & -0.07 \\
\hline & CAPITAL GOODS $_{\mathrm{t}-1, \mathrm{t}}$ & 0.65 & 5.10 & 0.19 & 0.14 & 0.17 & -0.08 & -0.01 & -0.12 & -0.10 \\
\hline & CONSTRUCTION $_{\mathrm{t}-1, \mathrm{t}}$ & 0.53 & 5.62 & 0.21 & 0.10 & 0.17 & -0.06 & 0.02 & -0.14 & -0.07 \\
\hline & CONSUMER GDS $_{\mathrm{t}-1, \mathrm{t}}$ & 0.68 & 4.44 & 0.22 & 0.15 & 0.20 & -0.09 & 0.00 & -0.10 & -0.05 \\
\hline & ENERGY $_{\mathrm{t}-1, \mathrm{t}}$ & 0.72 & 5.03 & 0.16 & 0.03 & 0.12 & 0.04 & -0.03 & -0.18 & -0.06 \\
\hline & FINANCE $_{t-1, t}$ & 0.66 & 4.39 & 0.23 & 0.14 & 0.21 & -0.09 & 0.04 & -0.10 & -0.09 \\
\hline & TRANSPORTN $_{\mathrm{t}-1, \mathrm{t}}$ & 0.58 & 5.40 & 0.23 & 0.13 & 0.21 & -0.06 & 0.03 & -0.11 & -0.06 \\
\hline & UTILITIES $_{\mathrm{t}-1, \mathrm{t}}$ & 0.49 & 3.30 & 0.16 & 0.11 & 0.15 & -0.13 & 0.06 & -0.02 & -0.09 \\
\hline & LONGBOND $_{\mathrm{t}-1, \mathrm{t}}$ & 0.04 & 2.50 & 0.05 & 0.11 & 0.06 & -0.13 & 0.16 & 0.06 & -0.07 \\
\hline & INTRMDBOND $_{\mathrm{t}-1, \mathrm{t}}$ & 0.08 & 1.40 & 0.04 & 0.10 & 0.05 & -0.12 & 0.17 & 0.08 & -0.07 \\
\hline & ONEYRBOND $_{\mathrm{t}-1, \mathrm{t}}$ & 0.07 & 0.44 & 0.02 & 0.12 & 0.04 & -0.10 & 0.15 & 0.07 & -0.04 \\
\hline & JUNKBOND $_{\mathrm{t}-1, \mathrm{t}}$ & 0.21 & 2.22 & 0.21 & 0.14 & 0.20 & -0.13 & 0.09 & 0.02 & -0.10 \\
\hline \multirow{9}{*}{$\mathrm{Z}$} & $\mathrm{RF}_{\mathrm{t}-1, \mathrm{t}}$ & 0.40 & 0.26 & -0.37 & -0.42 & -0.46 & 0.53 & -0.21 & 0.10 & 0.93 \\
\hline & TERMLONG $_{\mathrm{t}-1}$ & 1.40 & 1.31 & 0.34 & 0.22 & 0.27 & -0.24 & 0.19 & 0.37 & -0.14 \\
\hline & TERM1YR $_{\mathrm{t}-1}$ & 0.51 & 0.50 & -0.04 & 0.04 & -0.10 & 0.26 & -0.03 & 0.19 & 0.47 \\
\hline & DEFBOND $_{t-1}$ & 0.93 & 0.44 & 0.02 & -0.04 & -0.12 & 0.24 & 0.03 & 0.18 & 0.62 \\
\hline & $\mathrm{DEFCP}_{\mathrm{t}-1}$ & 0.68 & 0.47 & -0.32 & -0.20 & -0.37 & 0.25 & 0.01 & 0.01 & 0.34 \\
\hline & DIVYIELD $_{\mathrm{t}-1}$ & 3.95 & 1.09 & -0.02 & -0.13 & 0.03 & 0.04 & 0.40 & 0.00 & -0.09 \\
\hline & Production $_{t-13, t-1}$ & 3.62 & 6.25 & -0.28 & 0.01 & -0.09 & 0.10 & -0.27 & -0.07 & -0.12 \\
\hline & Inflation $_{\mathrm{t}-13, \mathrm{t}-1}$ & 4.23 & 3.44 & -0.37 & -0.40 & -0.50 & 0.60 & -0.16 & -0.08 & 0.49 \\
\hline & Excess stock returns $_{\mathrm{t}-13, \mathrm{t}-1}$ & 6.11 & 15.25 & 0.28 & 0.16 & 0.40 & -0.21 & $\begin{array}{l}-0.19 \\
\end{array}$ & -0.18 & -0.17 \\
\hline
\end{tabular}

Economic Tracking Portfolios - Page 37 


\section{Notes to Table 1}

Production growth $\mathrm{t}_{\mathrm{t}, \mathrm{t}+12}$ is (in percentage points) the change in natural $\log$ of industrial production from month $\mathrm{t}$ to month $\mathrm{t}+12$. Labor income growth $\mathrm{t}_{\mathrm{t}, \mathrm{t}+12}$ is (in percentage points) the change in natural $\log$ of real personal income from wages and salaries from month $t$ to month $t+12$. Inflation ${ }_{t, t+12}$ is (in percentage points) the change in natural log of the CPI index, from month $t$ to month $t+12$. Excess stock returns $_{t, t+12}$ is the continuously compounded total return, in percent, on the CRSP value weighted NYSE/AMEX/NASDAQ portfolio, minus the continuously compounded return on a portfolio of Treasury bills, from month $t$ to month $t+12$. Excess bond returns $s_{t, t+12}$ is the continuously compounded return, in percent, on the long term government bond portfolio, minus the continuously compounded return on a portfolio of Treasury bills, from month $t$ to month $t+12$. Nom. T-bill returns $\mathrm{s}_{\mathrm{t}, \mathrm{t}+12}$ is the continuously compounded return on a portfolio of Treasury bills, from month $t$ to month $t+12$. $R M R F_{t-1, t}$ is the simple return in month $t$, in percent (with reinvested dividends), on the CRSP value weighted NYSE/AMEX/NASDAQ portfolio, minus the simple return on a portfolio of Treasury bills. BASIC INDUSTRIES, CAPITAL GOODS, CONSTRUCTION, CONSUMER GDS, ENERGY, FINANCE, TRANSPORTATION, and UTILITIES are simple returns in month $\mathrm{t}$, in percent (with reinvested dividends), on the value weighted industry stock portfolios constructed from CRSP data, minus the simple return on a portfolio of Treasury bills. The industries are constructed using CRSP SIC codes and the classification system given in Table A. LONGBOND is the simple return in month $\mathrm{t}$, in percent, on the long term government bond portfolio, minus the simple return on a portfolio of Treasury bills. INTRMDBOND is the simple return in month $t$, in percent, on the intermediate term government bond portfolio, minus the simple return on a portfolio of Treasury bills. ONEYRBOND is the simple return in month $t$, in percent, on the one-year maturity bond portfolio, minus the simple return on a portfolio of Treasury bills. JUNKBOND is the simple return in month $t$, in percent, on the high yield corporate bond portfolio, minus the simple return on a portfolio of Treasury bills. RF is the simple return in month $t$ on a portfolio of Treasury bills. TERMLONG is the term premium for long term bonds, in percent in month $t-1$, calculated as the yield on the long term government bond portfolio minus the Treasury bill yield. TERM1YR is the term premium for oneyear bonds, in percent in month $\mathrm{t}-1$, calculated as the yield on the one-year government bond portfolio minus the Treasury bill yield. DEFBOND is the default premium for bonds, in percent in month $t-1$, calculated as the yield on AAA corporates minus the yield on BAA corporates. DEFCP is the default premium for commercial paper, in percent in month t-1, calculated as the yield on 3-6 month commercial paper minus the Treasury bill yield. DIVYIELD is the dividend yield, in percent in month $\mathrm{t}-1$, on the value weighted NYSE/AMEX/NASDAQ portfolio, calculated as the sum of the past 12 months of dividends divided by the level of market value of the portfolio. All data are monthly, 1947:1-1994:12, with the exception of consumption which is 1959:1-1994:12. 
Table 2

Regression coefficients and portfolio weights, $\mathrm{y}_{\mathrm{t}+12}=\mathrm{bR}_{\mathrm{t}-1, \mathrm{t}}+\mathrm{cZ} \mathrm{Z}_{\mathrm{t}-1}+\varepsilon_{\mathrm{t}, \mathrm{t}+12}$

\begin{tabular}{|c|c|c|c|c|c|c|c|c|c|c|c|c|c|c|c|}
\hline & & \multicolumn{2}{|c|}{$\begin{array}{l}\text { Production } \\
\text { growth }_{\mathrm{t}, \mathrm{t}+12}\end{array}$} & \multicolumn{2}{|c|}{$\begin{array}{l}\text { Consumption } \\
\text { growth }_{\mathrm{t}, \mathrm{t}+12}\end{array}$} & \multicolumn{2}{|c|}{$\begin{array}{l}\text { Labor income } \\
\text { growth }_{\mathrm{t}, \mathrm{t}+12}\end{array}$} & \multicolumn{2}{|c|}{ Inflation $_{t, t+12}$} & \multicolumn{2}{|c|}{$\begin{array}{l}\text { Excess stock } \\
\text { returns } \\
\mathrm{t}, \mathrm{t}+12\end{array}$} & \multicolumn{2}{|c|}{$\begin{array}{l}\text { Excess bond } \\
\text { returns } s_{t, t+12}\end{array}$} & \multicolumn{2}{|c|}{$\begin{array}{l}\text { Nom. T-bill } \\
\text { returns } \\
\mathrm{t}_{\mathrm{t}, \mathrm{t}+12}\end{array}$} \\
\hline \multirow{14}{*}{$\mathrm{R}_{\mathrm{t}-1, \mathrm{t}}$} & & Coef & SE & Coef & SE & Coef & SE & Coef & SE & Coef & $\mathrm{SE}$ & Coef & SE & Coef & SE \\
\hline & $\mathrm{RMRF}_{\mathrm{t}-1, \mathrm{t}}$ (market) & -0.38 & 0.33 & 0.11 & 0.11 & 0.20 & 0.16 & -0.40 & 0.24 & 2.94 & 0.73 & 3.98 & 0.63 & -0.30 & 0.07 \\
\hline & BASIC INDUSTRIES $_{\mathrm{t}-1, \mathrm{t}}$ & 0.03 & 0.09 & -0.02 & 0.03 & -0.08 & 0.05 & 0.17 & 0.07 & -0.71 & 0.35 & -0.66 & 0.15 & 0.06 & 0.02 \\
\hline & CAPITAL GOODS $_{\mathrm{t}-1, \mathrm{t}}$ & -0.16 & 0.14 & -0.02 & 0.04 & -0.16 & 0.08 & 0.03 & 0.06 & -0.85 & 0.29 & -0.53 & 0.20 & 0.03 & 0.02 \\
\hline & CONSTRUCTION $_{\mathrm{t}-1, \mathrm{t}}$ & 0.02 & 0.08 & -0.05 & 0.03 & -0.04 & 0.04 & 0.05 & 0.05 & 0.14 & 0.22 & -0.32 & 0.16 & 0.03 & 0.02 \\
\hline & CONSUMER GDS $_{\mathrm{t}-1, \mathrm{t}}$ & 0.20 & 0.12 & 0.02 & 0.04 & 0.06 & 0.07 & 0.00 & 0.07 & -0.73 & 0.42 & -0.93 & 0.26 & 0.08 & 0.03 \\
\hline & ENERGY $_{\mathrm{t}-1, \mathrm{t}}$ & 0.13 & 0.06 & -0.04 & 0.02 & -0.03 & 0.03 & 0.11 & 0.04 & -0.42 & 0.16 & -0.79 & 0.13 & 0.06 & 0.01 \\
\hline & FINANCE $_{\mathrm{t}-1, \mathrm{t}}$ & 0.14 & 0.08 & 0.01 & 0.04 & 0.08 & 0.05 & 0.04 & 0.04 & -0.37 & 0.25 & -0.35 & 0.12 & 0.03 & 0.01 \\
\hline & TRANSPORTATION $_{\mathrm{t}-1, \mathrm{t}}$ & 0.20 & 0.08 & 0.02 & 0.02 & 0.10 & 0.04 & 0.03 & 0.03 & 0.00 & 0.21 & -0.36 & 0.12 & 0.03 & 0.02 \\
\hline & UTILITIES $_{\mathrm{t}-1, \mathrm{t}}$ & -0.09 & 0.10 & -0.04 & 0.05 & -0.10 & 0.05 & -0.01 & 0.07 & -0.62 & 0.26 & -0.32 & 0.19 & 0.02 & 0.02 \\
\hline & LONGBOND $_{\mathrm{t}-1, \mathrm{t}}$ & -0.08 & 0.10 & 0.03 & 0.03 & -0.06 & 0.05 & -0.01 & 0.04 & -0.19 & 0.26 & -0.68 & 0.20 & 0.02 & 0.03 \\
\hline & INTRMDBOND $_{\mathrm{t}-1, \mathrm{t}}$ & -0.15 & 0.14 & -0.12 & 0.07 & -0.09 & 0.08 & 0.13 & 0.07 & 0.58 & 0.64 & 0.16 & 0.47 & -0.06 & 0.07 \\
\hline & ONEYRBOND $_{\mathrm{t}-1, \mathrm{t}}$ & 1.13 & 0.63 & 0.56 & 0.20 & 0.85 & 0.32 & -1.10 & 0.44 & 4.15 & 2.11 & 2.28 & 1.27 & -0.81 & 0.26 \\
\hline & $\mathrm{JUNKBOND}_{\mathrm{t}-1, \mathrm{t}}$ & 0.11 & 0.12 & -0.01 & 0.04 & 0.05 & 0.07 & 0.02 & 0.05 & -0.38 & 0.28 & 0.07 & 0.16 & 0.00 & 0.03 \\
\hline \multirow{11}{*}{$\mathrm{Z}_{\mathrm{t}-1}$} & Constant & 7.82 & 2.78 & 2.76 & 0.97 & 4.03 & 1.78 & 1.96 & 1.43 & -11.95 & 6.61 & -10.28 & 4.03 & 0.69 & 0.43 \\
\hline & $\mathrm{RF}_{\mathrm{t}-1, \mathrm{t}}$ & -11.20 & 2.95 & -4.65 & 1.59 & -6.05 & 1.76 & 4.59 & 1.80 & -6.72 & 5.33 & 11.08 & 6.58 & 9.84 & 0.74 \\
\hline & TERMLONG $_{\mathrm{t}-1}$ & -0.05 & 0.50 & -0.20 & 0.18 & -0.12 & 0.34 & -0.29 & 0.23 & 2.99 & 1.15 & 3.93 & 0.98 & -0.01 & 0.10 \\
\hline & TERM1YR $_{\mathrm{t}-1}$ & 1.95 & 0.86 & 0.29 & 0.28 & 0.82 & 0.48 & 0.89 & 0.41 & -0.87 & 1.55 & -2.51 & 1.59 & 0.62 & 0.22 \\
\hline & DEFBOND $_{\mathrm{t}-1}$ & 3.48 & 1.56 & 1.00 & 0.52 & 1.92 & 0.80 & -0.98 & 0.98 & -0.97 & 3.01 & -1.04 & 3.34 & 0.15 & 0.43 \\
\hline & DEFCP $_{t-1}$ & -1.82 & 0.86 & -0.02 & 0.27 & -0.53 & 0.45 & -0.30 & 0.42 & 1.50 & 2.03 & 1.34 & 1.26 & 0.06 & 0.20 \\
\hline & DIVYIELD $_{\mathrm{t}-1}$ & -0.22 & 0.60 & 0.75 & 0.36 & 0.18 & 0.32 & -0.15 & 0.40 & 6.64 & 1.38 & 1.38 & 0.79 & -0.16 & 0.09 \\
\hline & Production growth $_{\mathrm{t}-13, \mathrm{t}-1}$ & -0.30 & 0.09 & -0.02 & 0.03 & -0.06 & 0.05 & 0.05 & 0.03 & -0.49 & 0.21 & 0.07 & 0.11 & 0.01 & 0.01 \\
\hline & Inflation $_{t-13, t-1}$ & -0.32 & 0.25 & -0.20 & 0.10 & -0.29 & 0.10 & 0.41 & 0.14 & -1.30 & 0.30 & -0.64 & 0.31 & 0.07 & 0.05 \\
\hline & Excess stock returns $_{\mathrm{t}-13, \mathrm{t}-1}$ & 0.05 & 0.03 & 0.01 & 0.01 & 0.05 & 0.02 & 0.00 & 0.01 & -0.22 & 0.10 & -0.14 & 0.05 & 0.01 & 0.01 \\
\hline & $\mathrm{R} 2$ & 0.45 & & 0.38 & & 0.48 & & 0.54 & & 0.45 & & 0.35 & & 0.91 & \\
\hline
\end{tabular}

Economic Tracking Portfolios - Page 39 


\section{Notes to Table 2}

Shows seven different monthly OLS regressions of the form $y_{t+12}=b R_{t-1, t}+c Z_{t-1}+\varepsilon_{t, t+12} . y_{t+12}$ is a macroeconomic variable from month t to month $t+12, R_{t-1, t}$ is a vector of monthly returns in month $t$, and $Z_{t-1}$ is a vector of control variables observed in month $t-1$. See Table 1 for a description of all the variables. The sample period is 1947:1-1994:12, except for consumption which is 1959:1-1994:12. Robust standard errors are calculated with Newey-West 24 month lags. 
Table 3

Forecasting ability and descriptive statistics for tracking portfolios, 1947-1994

\begin{tabular}{llllll}
$\begin{array}{l}\text { Production } \\
\text { growth }\end{array}$ & $\begin{array}{l}\text { Consumption } \\
\text { growth }\end{array}$ & $\begin{array}{l}\text { Labor } \\
\text { income } \\
\text { growth }\end{array}$ & Inflation & $\begin{array}{l}\text { Excess } \\
\text { stock } \\
\text { returns }\end{array}$ & $\begin{array}{l}\text { Excess } \\
\text { bond } \\
\text { returns }\end{array}$ \\
\hline
\end{tabular}

Panel A -- P-values from exclusion tests on $\hat{b}$, in regression $y_{t+12}=b R_{t-1, t}+c Z_{t-1}+\varepsilon_{t, t+12}$

\begin{tabular}{llllllll} 
all returns & 0.00 & 0.00 & 0.00 & 0.00 & 0.00 & 0.00 & 0.00 \\
all except RMRF & 0.00 & 0.00 & 0.00 & 0.00 & 0.00 & 0.00 & 0.00 \\
eight industries & 0.00 & 0.42 & 0.00 & 0.00 & 0.00 & 0.00 & 0.00 \\
four bonds & 0.24 & 0.00 & 0.05 & 0.01 & 0.00 & 0.00 & 0.00 \\
\hline
\end{tabular}

Panel B -- Partial R2: R-squared from the regression of $y_{t+k}-E\left[y_{t+k} \mid Z_{t-1}\right]$ on $\hat{b} R_{t-1, t}-E\left[\hat{b}_{t-1, t} \mid Z_{t-1}\right]$

\begin{tabular}{lllllll}
0.05 & 0.04 & 0.06 & 0.10 & 0.08 & 0.12 & 0.23 \\
\hline
\end{tabular}

Panel C -- Summary statistics for portfolio returns: properties of $\hat{b} R_{t-1, t}$

\begin{tabular}{lrrrrrrr} 
Mean & 0.17 & 0.04 & 0.10 & -0.04 & -0.20 & -0.13 & -0.02 \\
Std Dev & 1.04 & 0.27 & 0.60 & 0.71 & 3.45 & 2.88 & 0.50 \\
(t-stat) & $(2.76)$ & $(2.06)$ & $(2.78)$ & \multicolumn{1}{c}{$(0.76)$} & $(0.89)$ & $(0.77)$ & $(0.66)$ \\
\hline \multicolumn{7}{l}{ Panel D -- Market model regression: } & $\hat{b}_{\mathrm{t}-1, \mathrm{t}}=\alpha+\beta\left(\mathrm{RMRF}_{\mathrm{t}-1, \mathrm{t}}\right)+\xi_{\mathrm{t}-1, \mathrm{t}}$ \\
$\alpha$ & 0.09 & 0.04 & 0.06 & -0.06 & 0.09 & 0.09 & -0.05 \\
(t-stat) & $(1.30)$ & $(2.32)$ & $(1.40)$ & $(1.50)$ & $(0.47)$ & $(0.59)$ & $(1.46)$ \\
$\beta$ & 0.14 & -0.00 & 0.06 & 0.05 & -0.48 & -0.36 & 0.04 \\
(t-stat) & $(3.24)$ & $(0.10)$ & $(2.25)$ & $(1.89)$ & $(5.45)$ & $(3.76)$ & $(3.09)$ \\
R2 & 0.32 & 0.00 & 0.20 & 0.07 & 0.33 & 0.27 & 0.10 \\
\hline
\end{tabular}

Panel E -- Correlation matrix for tracking portfolio returns and base asset returns

\begin{tabular}{|c|c|c|c|c|c|c|c|}
\hline Consumption & 0.14 & & & & & & \\
\hline Labor income & 0.82 & 0.59 & & & & & \\
\hline Inflation & 0.29 & -0.80 & -0.23 & & & & \\
\hline Excess stock & -0.26 & 0.54 & 0.10 & -0.70 & & & \\
\hline Excess bond & -0.57 & 0.42 & -0.10 & -0.73 & 0.68 & & \\
\hline Nom. T-bill & 0.21 & -0.68 & -0.17 & 0.85 & -0.80 & -0.62 & \\
\hline RMRF & 0.57 & -0.03 & 0.45 & 0.27 & -0.58 & -0.52 & 0.31 \\
\hline BASIC & 0.56 & -0.19 & 0.30 & 0.51 & -0.67 & -0.65 & 0.43 \\
\hline CAPITAL & 0.39 & -0.04 & 0.25 & 0.27 & -0.63 & -0.50 & 0.34 \\
\hline CONSTRUCT & 0.56 & -0.15 & 0.38 & 0.34 & -0.52 & -0.59 & 0.36 \\
\hline CONSUMER & 0.54 & 0.09 & 0.49 & 0.16 & -0.57 & -0.48 & 0.31 \\
\hline ENERGY & 0.56 & -0.36 & 0.23 & 0.53 & -0.52 & -0.61 & 0.40 \\
\hline FINANCE & 0.64 & 0.08 & 0.56 & 0.20 & -0.53 & -0.53 & 0.24 \\
\hline TRANSPORT & 0.71 & 0.04 & 0.59 & 0.30 & -0.48 & -0.56 & 0.34 \\
\hline UTILITIES & 0.37 & 0.03 & 0.37 & -0.06 & -0.37 & -0.29 & -0.02 \\
\hline LONGBOND & 0.17 & 0.45 & 0.31 & -0.41 & 0.26 & -0.15 & -0.55 \\
\hline INTRMDBOND & 0.20 & 0.41 & 0.34 & -0.44 & 0.38 & -0.03 & -0.69 \\
\hline ONEYRBOND & 0.31 & 0.60 & 0.46 & -0.54 & 0.45 & 0.06 & -0.78 \\
\hline JUNKBOND & 0.58 & 0.11 & 0.52 & 0.02 & -0.24 & -0.30 & -0.12 \\
\hline
\end{tabular}

Economic Tracking Portfolios - Page 41 
Notes to Table 3

Shows the properties of the tracking portfolios defined by the regressions in Table 2, $\mathrm{y}_{\mathrm{t}+12}=\mathrm{bR}_{\mathrm{t}-1, \mathrm{t}}+\mathrm{cZ} \mathrm{Z}_{\mathrm{t}-1}+\varepsilon_{\mathrm{t}, \mathrm{t}+12}$. Shows additional information about the statistical significance of returns in the regressions in Table 2. For consumption, all statistics are calculated using data from 1959:1-1994:12. For the other series, the data are 1947:1-1994:12.

A.) P-values report tests of the hypothesis that different elements of $\mathrm{R}_{\mathrm{t}-1, \mathrm{t}}$ can be omitted from the regressions in Table 2. "all returns" tests whether all 13 base assets can be omitted from the regressions in Table 2. "all except RMRF" tests whether the 8 industry stock portfolios and 4 bond portfolios can be omitted from the regressions in Table 2. "eight industries" tests whether the 8 industry stock portfolios can be omitted from the regressions in Table 2. "four bonds" tests whether the 4 bond portfolios can be omitted from the regressions in Table 2. Pvalues are constructed using robust standard errors with Newey-West 24 month lags.

B.) Shows R-squared in a regression where the left hand side is the residual from a regression of $\mathrm{y}_{\mathrm{t}+12}$ on $\mathrm{Z}_{\mathrm{t}-1}$, and the right hand side is the residual from a regression of $\hat{b}_{\mathrm{t}-1, \mathrm{t}}$ on $\mathrm{Z}_{\mathrm{t}-1} . \hat{\mathrm{b}}$ is derived from the regression in Table 2

C.) Summary statistics show mean, standard deviation, and t-statistic for the monthly tracking portfolios, $\hat{b}_{\mathrm{t}-1, \mathrm{t}} . \hat{\mathrm{b}}$ is derived from the regression in Table 2 . The mean and standard deviation are simply the time series statistics for $\hat{b}_{t-1, t}$. The t-statistic tests the hypothesis that $\hat{b}_{\mathrm{t}-1, \mathrm{t}}$ is zero, using GMM standard errors. The GMM standard errors take into account the estimation error of $\hat{b}$.

D.) Market model regressions show univariate regressions of tracking portfolio returns on the market excess return. $\hat{b}$ is derived from the regression in Table 2. The t-statistics use GMM standard errors, which take into account the estimation error of $\hat{b}$.

E.) The correlation matrix shows correlations of tracking portfolio returns $\hat{b} R_{t-1, t}$ with itself and with base asset returns $R_{t-1, t}$, using monthly data. $\hat{b}$ is derived from the regression in Table 2 . 
Table 4

Correlation matrix for innovations: Tracking portfolios vs. vector autoregressions

Panel A

VAR innovations from Campbell and Ammer (1993)

\begin{tabular}{|c|c|c|c|}
\hline & $\begin{array}{l}\text { Innovation in future } \\
\text { excess stock returns }\end{array}$ & $\begin{array}{l}\text { Innovation in future } \\
\text { real interest rates }\end{array}$ & $\begin{array}{l}\text { Innovation in future } \\
\text { inflation }\end{array}$ \\
\hline & \multicolumn{3}{|c|}{ 1952:1-1987:2 } \\
\hline $\begin{array}{l}\text { Innovation in future } \\
\text { real interest rates }\end{array}$ & $\begin{array}{r}0.42 \\
(0.27)\end{array}$ & & \\
\hline $\begin{array}{l}\text { Innovation in future } \\
\text { inflation }\end{array}$ & $\begin{array}{r}-0.65 \\
(0.23) \\
\end{array}$ & $\begin{array}{r}-0.30 \\
(0.17) \\
\end{array}$ & \\
\hline $\begin{array}{l}\text { Innovation in future } \\
\text { excess bond returns }\end{array}$ & $\begin{array}{r}0.82 \\
(0.17)\end{array}$ & $\begin{array}{r}0.48 \\
(0.22)\end{array}$ & $\begin{array}{r}-0.54 \\
(0.14)\end{array}$ \\
\hline
\end{tabular}

Panel B

Correlation matrix for unexpected tracking portfolio return

\begin{tabular}{|c|c|c|c|}
\hline & $\begin{array}{l}\text { Unexpected return on excess } \\
\text { stock return portfolio }\end{array}$ & $\begin{array}{l}\text { Unexpected return on real } \\
\text { T-bill return portfolio }\end{array}$ & $\begin{array}{l}\text { Unexpected return on } \\
\text { inflation portfolio }\end{array}$ \\
\hline & \multicolumn{3}{|c|}{ 1947:1-1994:12 } \\
\hline $\begin{array}{l}\text { Unexpected return on } \\
\text { real T-bill return portfolio }\end{array}$ & $\begin{array}{r}0.24 \\
(0.36)\end{array}$ & & \\
\hline $\begin{array}{l}\text { Unexpected return on } \\
\text { inflation portfolio }\end{array}$ & $\begin{array}{r}-0.70 \\
(0.17)\end{array}$ & $\begin{array}{r}-0.74 \\
(0.17)\end{array}$ & \\
\hline \multirow[t]{2}{*}{$\begin{array}{l}\text { Unexpected return on } \\
\text { excess bond return portfolio }\end{array}$} & $\begin{array}{r}0.67 \\
(0.13)\end{array}$ & $\begin{array}{r}0.53 \\
(0.22) \\
\end{array}$ & $\begin{array}{r}-0.72 \\
(0.11) \\
\end{array}$ \\
\hline & \multicolumn{3}{|c|}{ 1952:1-1987:2 } \\
\hline $\begin{array}{l}\text { Unexpected return on } \\
\text { real T-bill return portfolio }\end{array}$ & $\begin{array}{r}-0.06 \\
(0.40) \\
\end{array}$ & & \\
\hline $\begin{array}{l}\text { Unexpected return on } \\
\text { inflation portfolio }\end{array}$ & $\begin{array}{r}-0.58 \\
(0.23)\end{array}$ & $\begin{array}{r}-0.66 \\
(0.19)\end{array}$ & \\
\hline $\begin{array}{l}\text { Unexpected return on } \\
\text { excess bond return portfolio }\end{array}$ & $\begin{array}{r}0.58 \\
(0.18)\end{array}$ & $\begin{array}{r}0.50 \\
(0.24)\end{array}$ & $\begin{array}{r}-0.77 \\
(0.09)\end{array}$ \\
\hline
\end{tabular}

Panel A reprints Table V from Campbell and Ammer (1993). Panel B reports the correlation of unexpected returns on tracking portfolios, $\widetilde{\mathrm{r}}_{\mathrm{t}-1, \mathrm{t}}$, calculated as the residual in the regression $\hat{\mathrm{b}} \mathrm{R}_{\mathrm{t}-1, \mathrm{t}}=a \mathrm{Z}_{\mathrm{t}-1}+\tilde{\mathrm{r}}_{\mathrm{t}-1, \mathrm{t}}$. The standard errors, in parenthesis, are calculated using GMM and take into account the estimation error in the portfolio weights. The real T-bill return tracking portfolio is defined as the nominal T-bill return tracking portfolio minus the inflation tracking portfolio. The tracking portfolio returns are defined by Table 2 (except that the 1952:1-1987:2 sample in panel B uses a different sample period to estimate equations (5) and (9)). 
Table 5

Explaining aggregate stock returns using future industrial production growth: OLS vs. IV

\begin{tabular}{|c|c|c|c|c|c|c|c|c|}
\hline & \multicolumn{2}{|c|}{ OLS } & \multicolumn{2}{|c|}{ OLS } & \multicolumn{2}{|c|}{ OLS } & \multicolumn{2}{|c|}{ Instrumental Variables } \\
\hline & Coef & SE & Coef & SE & Coef & SE & Coef & SE \\
\hline Constant & -0.83 & 0.94 & -0.17 & 0.92 & -1.60 & 0.98 & -21.69 & 11.15 \\
\hline $\mathrm{RF}_{\mathrm{t}-1, \mathrm{t}}$ & -3.20 & 1.20 & -3.55 & 1.16 & -2.05 & 1.26 & 27.96 & 15.00 \\
\hline TERMLONG $_{\mathrm{t}-1}$ & 0.11 & 0.20 & -0.04 & 0.19 & 0.11 & 0.19 & 0.11 & 1.47 \\
\hline TERM1YR $_{\mathrm{t}-1}$ & -0.69 & 0.44 & -0.70 & 0.42 & -0.85 & 0.44 & -5.07 & 3.25 \\
\hline DEFBOND $_{\mathrm{t}-1}$ & 2.24 & 0.70 & 2.23 & 0.68 & 1.84 & 0.71 & -8.56 & 6.08 \\
\hline $\mathrm{DEFCP}_{\mathrm{t}-1}$ & -0.16 & 0.48 & -0.35 & 0.46 & 0.03 & 0.48 & 5.20 & 3.63 \\
\hline DIVYIELD $_{\mathrm{t}-1}$ & 0.39 & 0.17 & 0.28 & 0.17 & 0.41 & 0.17 & 0.74 & 1.64 \\
\hline Production growth ${ }_{\mathrm{t}-13, \mathrm{t}-1}$ & -0.02 & 0.03 & -0.02 & 0.03 & 0.01 & 0.03 & 0.81 & 0.37 \\
\hline Inflation $_{\mathrm{t}-13, \mathrm{t}-1}$ & -0.11 & 0.06 & -0.06 & 0.06 & -0.08 & 0.06 & 0.81 & 0.80 \\
\hline Excess stock returns $_{\mathrm{t}-13, \mathrm{t}-1}$ & -0.01 & 0.01 & 0.00 & 0.01 & -0.02 & 0.01 & -0.15 & 0.07 \\
\hline LONGBOND $_{\mathrm{t}-1, \mathrm{t}}$ & & & 0.44 & 0.07 & & & & \\
\hline Industrial Production $_{t, t+12}$ & & & & & 0.10 & 0.04 & 2.77 & 0.96 \\
\hline $\mathrm{R} 2$ & 0.08 & & 0.14 & & 0.09 & & 0.25 & \\
\hline
\end{tabular}

Shows three OLS regressions, and an instrumental variable regression. The dependent variable is excess return on the aggregate stock market in month $\mathrm{t}, \mathrm{RMRF}_{\mathrm{t}-1, \mathrm{t}}$. In the instrumental variables regression, the instruments include the $10 \mathrm{Z}_{\mathrm{t}-1}$ terms that are on the righthand side of the regression, plus four bond portfolio returns. The variable that is instrumented out is the growth in industrial production from the month $\mathrm{t}$ to month $\mathrm{t}+12$. The OLS regressions report simple standard errors; the instrumental variable regressions report robust standard errors with Newey-West 24 month lags. The sample period is 1947:1-1994:12. 
Table 6

Explaining aggregate bond returns using future excess bond returns and future Treasury-bill returns: OLS vs. IV

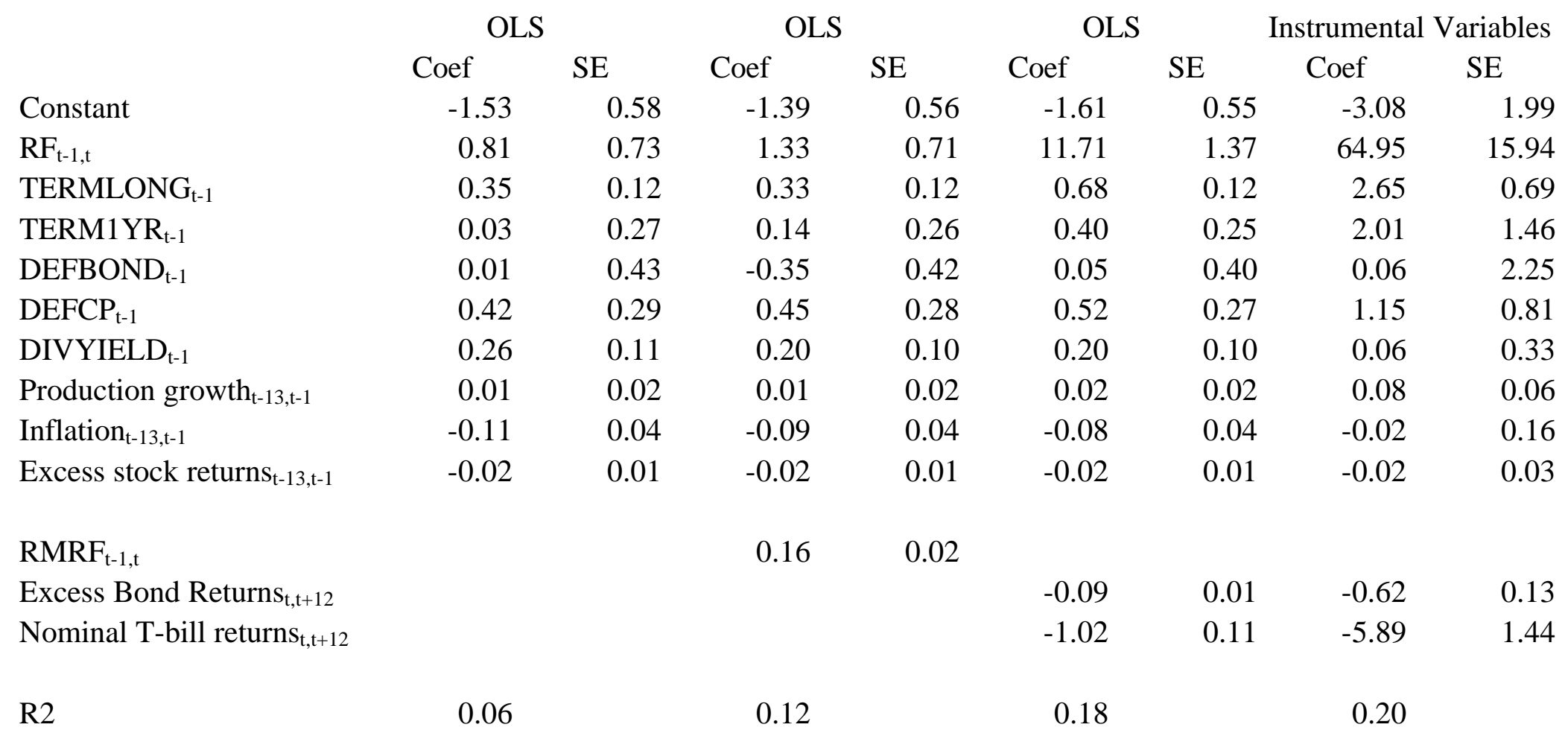

Shows three OLS regressions, and an instrumental variable regression. The dependent variable is excess return on the long term government bonds in month $\mathrm{t}, \mathrm{LONGBOND}_{\mathrm{t}-1, \mathrm{t}}$. In the instrumental variables regression, the instruments include the $10 \mathrm{Z}_{\mathrm{t}-1}$ terms that are on the right-hand side of the regression, plus nine stock portfolio returns. The variables that are instrumented out are the excess returns on long term government bonds from month $t$ to month $t+12$, and the return on T-bills from month $t$ to month $t+12$. The OLS regressions report simple standard errors; the instrumental variable regressions report robust standard errors with Newey-West 24 month lags. The sample period is 1947:1-1994:12. 
Table 7

Explaining small stock returns using current market returns and future industrial production growth: OLS vs. IV

\begin{tabular}{|c|c|c|c|c|c|c|c|c|}
\hline & \multicolumn{2}{|c|}{ OLS } & \multicolumn{2}{|c|}{ OLS } & \multicolumn{2}{|c|}{ OLS } & \multicolumn{2}{|c|}{ Instrumental Variables } \\
\hline & Coef & $\mathrm{SE}$ & Coef & SE & Coef & $\mathrm{SE}$ & Coef & $\mathrm{SE}$ \\
\hline Constant & -0.32 & 1.28 & 0.64 & 0.69 & 0.27 & 0.72 & -8.12 & 4.11 \\
\hline $\mathrm{RF}_{\mathrm{t}-1, \mathrm{t}}$ & -4.23 & 1.63 & -0.57 & 0.88 & -0.05 & 0.93 & 11.80 & 5.75 \\
\hline TERMLONG $_{\mathrm{t}-1}$ & 0.02 & 0.27 & -0.11 & 0.14 & -0.11 & 0.14 & -0.10 & 0.62 \\
\hline TERM1YR $_{\mathrm{t}-1}$ & -1.09 & 0.59 & -0.31 & 0.32 & -0.39 & 0.32 & -2.22 & 1.31 \\
\hline DEFBOND $_{\mathrm{t}-1}$ & 3.30 & 0.95 & 0.74 & 0.52 & 0.57 & 0.53 & -3.36 & 2.62 \\
\hline $\mathrm{DEFCP}_{\mathrm{t}-1}$ & -0.36 & 0.65 & -0.17 & 0.35 & -0.08 & 0.35 & 2.02 & 1.50 \\
\hline DIVYIELD $_{\mathrm{t}-1}$ & 0.24 & 0.24 & -0.21 & 0.13 & -0.20 & 0.13 & -0.01 & 0.67 \\
\hline Production growth $_{\mathrm{t}-13, \mathrm{t}-1}$ & -0.03 & 0.04 & -0.01 & 0.02 & 0.00 & 0.02 & 0.33 & 0.12 \\
\hline Inflation $_{t-13, t-1}$ & -0.06 & 0.08 & 0.07 & 0.05 & 0.09 & 0.05 & 0.44 & 0.32 \\
\hline Excess stock returns $_{\mathrm{t}-13, \mathrm{t}-1}$ & 0.00 & 0.02 & 0.01 & 0.01 & 0.01 & 0.01 & -0.05 & 0.03 \\
\hline $\mathrm{RMRF}_{\mathrm{t}-1, \mathrm{t}}$ & & & 1.15 & 0.03 & 1.14 & 0.03 & 0.99 & 0.07 \\
\hline Industrial Production $_{t, t+12}$ & & & & & 0.05 & 0.03 & 1.14 & 0.28 \\
\hline $\mathrm{R} 2$ & 0.06 & & 0.73 & & 0.73 & & 0.76 & \\
\hline
\end{tabular}

Shows three OLS regressions, and an instrumental variable regression. The dependent variable is excess return on a portfolio of small stocks in month $t$. The portfolio of small stocks consists of all stocks on NYSE/AMEX/NASDAQ with market capitalization in the bottom quintile of NYSE stocks. In the instrumental variables regression, the instruments include the $10 \mathrm{Z}_{\mathrm{t}-1}$ terms that are on the right-hand side of the regression, plus the 13 portfolio returns including 9 stock and 4 bond portfolios. The variable that is instrumented out is the growth in industrial production from the month $t$ to month $t+12$. The OLS regressions report simple standard errors; the instrumental variable regressions report robust standard errors with Newey-West 24 month lags. The sample period is 1947:1-1994:12. 
Table 8

Out-of sample results using rolling regressions

\begin{tabular}{|c|c|c|c|c|c|c|c|}
\hline & $\begin{array}{l}\text { Production } \\
\text { growth }\end{array}$ & $\begin{array}{l}\text { Consumption } \\
\text { growth }\end{array}$ & $\begin{array}{l}\text { Labor } \\
\text { income } \\
\text { growth }\end{array}$ & Inflation & $\begin{array}{l}\text { Excess } \\
\text { stock } \\
\text { returns }\end{array}$ & $\begin{array}{l}\text { Excess } \\
\text { bond } \\
\text { returns }\end{array}$ & $\begin{array}{l}\text { Nom. T-bill } \\
\text { returns }\end{array}$ \\
\hline \multicolumn{8}{|c|}{$\mathrm{y}_{\mathrm{t}+12}=\kappa+\lambda \hat{\mathrm{b}}_{\mathrm{t}} \mathrm{R}_{\mathrm{t}-1, \mathrm{t}}+\pi \hat{c}_{t} \mathrm{Z}_{\mathrm{t}-1}+\xi_{\mathrm{t}, \mathrm{t}+12}$} \\
\hline \multicolumn{8}{|c|}{ Panel A: 20 Year Estimation } \\
\hline$\hat{\lambda}$ & 0.40 & 0.45 & 0.56 & 0.56 & 0.37 & 0.73 & 0.66 \\
\hline (t-stat) & $(2.21)$ & $(3.66)$ & $(5.49)$ & $(4.21)$ & $(2.65)$ & $(3.33)$ & $(4.02)$ \\
\hline$\hat{\pi}$ & 0.67 & 0.48 & 0.56 & 0.54 & 0.27 & 0.29 & 1.03 \\
\hline (t-stat) & $(7.01)$ & $(9.63)$ & $(8.24)$ & $(4.13)$ & $(1.43)$ & $(1.60)$ & $(10.25)$ \\
\hline $\mathrm{R} 2$ & 0.34 & 0.36 & 0.37 & 0.36 & 0.04 & 0.09 & 0.67 \\
\hline \multicolumn{8}{|c|}{ Panel B: 5 Year Estimation } \\
\hline$\hat{\lambda}$ & -0.22 & 0.16 & 0.04 & -0.02 & -0.11 & 0.26 & 0.22 \\
\hline$(\mathrm{t}-\mathrm{stat})$ & $(0.77)$ & $(0.80)$ & $(0.19)$ & $(0.06)$ & $(1.08)$ & $(1.33)$ & $(0.74)$ \\
\hline$\hat{\pi}$ & 0.06 & 0.26 & 0.19 & 0.50 & 0.16 & 0.05 & 0.71 \\
\hline (t-stat) & $(0.46)$ & $(3.51)$ & $(1.41)$ & $(3.51)$ & $(1.65)$ & $(0.77)$ & $(6.24)$ \\
\hline $\mathrm{R} 2$ & 0.01 & 0.14 & 0.07 & 0.30 & 0.06 & 0.01 & 0.61 \\
\hline
\end{tabular}

Every month, for each target variable, the rolling regression procedure estimates the OLS regression $\mathrm{y}_{\mathrm{t}+12}=\mathrm{bR}_{\mathrm{t}-1, \mathrm{t}}+\mathrm{cZ}_{\mathrm{t}-1}+\varepsilon_{\mathrm{t}, \mathrm{t}+12}$. This regression uses $\mathrm{j}$ months of past data (the target variable data is from month $t-j-1$ to $t$ and the return data is from month $t-j-11$ to $t-12$ ). For the 20 -year rolling estimation, $j=240$ months; for the 5 -year estimation period, $j=60$ months. Each month, this regression produces a $\hat{b}_{t}$ and $\hat{c}_{t}$. After calculating a time series of $\hat{b}_{t}$ and $\hat{c}_{t}$, the table reports the results from the out-of sample regression $\mathrm{y}_{\mathrm{t}+12}=\kappa+\lambda \hat{\mathrm{b}}_{\mathrm{t}} \mathrm{R}_{\mathrm{t}-1, \mathrm{t}}+\pi \hat{c}_{t} \mathrm{Z}_{\mathrm{t}-1}+\xi_{\mathrm{t}, \mathrm{t}+12}$. The constant term, $\kappa$, is not shown. For the twenty-year rolling regressions, the sample period for the reported regression is 1967:12-1994:12(1979:12-1994:12 for Consumption). For the fiveyear rolling regressions, the sample period is 1952:12-1994:12 (1964:12-1994:12 for Consumption). The t-statistics are OLS time-series statistics, using robust standard errors with Newey-West 24 month lags. 
Table 9

Tracking portfolios constructed using alternative methods

$\begin{array}{lllllll}\begin{array}{l}\text { Production } \\ \text { growth }\end{array} & \begin{array}{l}\text { Consumption } \\ \text { growth }\end{array} & \begin{array}{l}\text { Labor } \\ \text { income } \\ \text { growth }\end{array} & \text { Inflation } & \begin{array}{l}\text { Excess } \\ \text { stock } \\ \text { returns }\end{array} & \begin{array}{l}\text { Excess } \\ \text { bond } \\ \text { returns }\end{array} & \begin{array}{l}\text { Nom. T-bill } \\ \text { returns }\end{array} \\ & & & \end{array}$

P-values from exclusion test Panel A -- Baseline

Partial R2

$\begin{array}{lll}0.00 & 0.00 & 0.00 \\ 0.05 & 0.04 & 0.06 \\ 1.00 & 1.00 & 1.00\end{array}$

0.00
0.10

$0.00 \quad 0.00$

$0.08 \quad 0.12$

1.00

Correlation with baseline portfolio

$$
1.00 \quad 1.00 \quad 1.00
$$

1.00

Panel B -- 60 Month Ahead Target Variable: $\mathrm{y}_{\mathrm{t}+60}=\mathrm{bR}_{\mathrm{t}-1, \mathrm{t}}+\mathrm{c} \mathrm{Z}_{\mathrm{t}-1}+\varepsilon_{\mathrm{t}, \mathrm{t}+60}$

P-values from exclusion test

$\begin{array}{lllll}0.00 & 0.00 & 0.00 & 0.00 & 0.00 \\ 0.04 & 0.03 & 0.03 & 0.03 & 0.08\end{array}$

0.00

\section{Partial R2}

0.27

0.50

0.58

$0.81 \quad 0.84$

0.07

0.08

0.70

0.79

Panel C -- 3 Month Base Asset Returns: $\mathrm{y}_{\mathrm{t}+12}=\mathrm{bR}_{\mathrm{t}-3, \mathrm{t}}+\mathrm{cZ} \mathrm{Z}_{\mathrm{t}-3}+\varepsilon_{\mathrm{t}, \mathrm{t}+12}$

P-values from exclusion test

$\begin{array}{lllll}0.00 & 0.03 & 0.00 & 0.00 & 0.00 \\ 0.09 & 0.10 & 0.12 & 0.19 & 0.22\end{array}$

0.00

0.00

\section{Partial R2}

0.09

0.10

0.12

0.19

0.22

0.23

0.34

Correlation with baseline portfolio

0.91

0.92

0.96

0.97

0.95

0.97

0.94

P-values from exclusion test

Panel D -- Stock only in base assets: $\mathrm{y}_{\mathrm{t}+12}=\mathrm{bR}_{\mathrm{t}-1, \mathrm{t}}+\mathrm{cZ} \mathrm{Z}_{\mathrm{t}-1}+\varepsilon_{\mathrm{t}, \mathrm{t}+12}$

\section{Partial R2}

$$
0.00
$$

0.52

$\begin{array}{ll}0.00 & 0.00 \\ 0.05 & 0.08\end{array}$

0.02

0.00

0.00

0.00

Correlation with baseline portfolio

0.93

0.75

0.90

0.89

0.06

0.11

0.11

Panel E -- Bonds only in base assets: $\mathrm{y}_{\mathrm{t}+12}=\mathrm{bR}_{\mathrm{t}-1, \mathrm{t}}+\mathrm{cZ} \mathrm{Z}_{\mathrm{t}-1}+\varepsilon_{\mathrm{t}, \mathrm{t}+12}$

P-values from exclusion test

$\begin{array}{llll}0.01 & 0.00 & 0.00 & 0.01 \\ 0.02 & 0.02 & 0.02 & 0.04\end{array}$

\section{Partial R2}

0.02

0.02

0.00

0.01

0.70

0.60

0.63

0.00

0.04

0.94

0.70

Panel F -- No control variables: $\mathrm{y}_{\mathrm{t}+12}=\mathrm{bR}_{\mathrm{t}-1, \mathrm{t}}+\mathrm{c}+\varepsilon_{\mathrm{t}, \mathrm{t}+12}$

P-values from exclusion test

Partial R2

$\begin{array}{llll}0.00 & 0.00 & 0.00 & 0.27 \\ 0.08 & 0.06 & 0.07 & 0.06 \\ 0.77 & 0.66 & 0.75 & 0.63\end{array}$

0.69

0.00

0.00

0.15

0.83

Correlation with baseline portfolio

0.66

0.75

0.63

0.00

0.06

0.63

0.01

0.03

0.09 


\section{Notes to table 9}

Table 9 shows results from different ways of estimating the regression $\mathrm{y}_{\mathrm{t}+\mathrm{k}}=\mathrm{bR}_{\mathrm{t}-\mathrm{j}, \mathrm{t}}+\mathrm{c} \mathrm{Z}_{\mathrm{t}-\mathrm{j}}+\varepsilon_{\mathrm{t}, \mathrm{t}+\mathrm{j}}$. The different ways of constructing tracking portfolios are choosing different values for $\mathrm{k}$ (target horizon), different values for $\mathrm{j}$ (base asset return period), and different compositions of $\mathrm{R}$ and $\mathrm{Z}$. "P-values from exclusion test" report tests of the hypothesis that $\mathrm{R}_{\mathrm{t}-\mathrm{j}, \mathrm{t}}$ can be omitted from the regression, and is constructed using robust standard errors with Newey-West 24 month lags (except in the case of 60-month ahead target

variables, which use 120 month lags). "Partial R2" is the R-squared from a regression of $y_{t+k}-E\left[y_{t+k} \mid Z_{t-j}\right]$ on $\hat{b} R_{t-j, t}-E\left[\hat{b}_{t-j, t} \mid Z_{t-j}\right]$; in other words, the R-squared in a regression where the left hand side is the residual from a regression of $\mathrm{y}_{\mathrm{t}+\mathrm{k}}$ on $\mathrm{Z}_{\mathrm{t}-\mathrm{j}}$, and the right hand

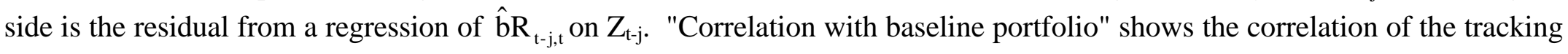
portfolio for the given target variable with the baseline tracking portfolio for the same target variable. The baseline tracking portfolio, $\hat{b}_{t-1, t}$ is derived from Table 2. For Panel B, the sample period is 1947:1-1990:12, except for consumption which is 1959:1-1990:12. For Panels A and C-F, the sample period is 1947:1-1994:12, except for consumption which is 1959:1-1994:12.

A) Reprints information from Table 3.

B) Uses 5-year ahead target variables.

C) Uses 3 month excess returns for base assets. The correlation with baseline portfolio is $\operatorname{corr}\left(\hat{b}^{\text {Table } 9 c} R_{t-1, t}, \hat{b}^{\text {Table } 2} R_{t-1, t}\right)$. In other words, the portfolio weights are taken from the regression $y_{t+12}=b R_{t-3, t}+c Z_{t-3}+\varepsilon_{t, t+12}$ but the returns are monthly.

D) The base asset return vector $\mathrm{R}_{\mathrm{t}-1, \mathrm{t}}$ includes only the nine stock market portfolio returns.

E) The base asset return vector $\mathrm{R}_{\mathrm{t}-1, \mathrm{t}}$ includes only the four bond market portfolio returns.

F) The control variable vector $\mathrm{Z}_{\mathrm{t}-1}$ includes only a constant term. The partial R-squared's are now equivalent to simple $\mathrm{R}$-squareds. 
Table 10

Value, size, and price momentum: Incremental forecasting power and correlation with tracking portfolio returns

\begin{tabular}{|c|c|c|c|c|c|c|c|}
\hline & $\begin{array}{l}\text { Production } \\
\text { growth }\end{array}$ & $\begin{array}{l}\text { Consumption } \\
\text { growth }\end{array}$ & $\begin{array}{l}\text { Labor } \\
\text { income } \\
\text { growth }\end{array}$ & Inflation & $\begin{array}{l}\text { Excess } \\
\text { stock } \\
\text { returns }\end{array}$ & $\begin{array}{l}\text { Excess } \\
\text { bond } \\
\text { returns }\end{array}$ & $\begin{array}{l}\text { Nom. T-bill } \\
\text { returns }\end{array}$ \\
\hline \multicolumn{8}{|c|}{ Value: HML } \\
\hline P-values from exclusion test & 0.66 & 0.12 & 0.32 & 0.94 & 0.71 & 0.09 & 0.44 \\
\hline $\begin{array}{l}\text { Correlation of HML } \\
\text { with tracking portfolio returns }\end{array}$ & 0.17 & -0.08 & 0.09 & 0.08 & 0.12 & -0.01 & -0.06 \\
\hline \multicolumn{8}{|c|}{ Size: SMB } \\
\hline P-values from exclusion test & 0.48 & 0.32 & 0.99 & 0.03 & 0.82 & 0.07 & 0.08 \\
\hline $\begin{array}{l}\text { Correlation with SMB } \\
\text { with tracking portfolio returns }\end{array}$ & 0.33 & -0.02 & 0.29 & 0.08 & -0.20 & -0.24 & 0.20 \\
\hline \multicolumn{8}{|c|}{ Price momentum: PR1YR } \\
\hline P-values from exclusion test & 0.49 & 0.39 & 0.73 & 0.86 & 0.31 & 0.88 & 0.25 \\
\hline Correlation of PR1YR & -0.13 & 0.04 & -0.10 & -0.03 & 0.10 & 0.06 & -0.07 \\
\hline
\end{tabular}

This table shows the incremental forecasting power of the value factor, the size factor, and the momentum factor, and the correlation of these three factors with tracking portfolio returns. "P-values from exclusion test" shows the test of the hypothesis that the candidate portfolio return has a zero coefficient, when added to the right-hand side of the regression in Table 2. "Correlation with tracking portfolio returns" shows the correlation of the candidate portfolio return with the economic tracking portfolios generated from the regressions in Table 2. HML, from Davis, Fama, and French (1999), is high minus low, which measures the book-to-market factor by subtracting returns of a portfolio of low book-to-market firm stocks from the returns of a portfolio of high book-to-market firm stocks. SMB, from Davis, Fama, and French (1999), is small minus big, which measures the size factor by subtracting returns of a portfolio of big firm stocks from the returns of a portfolio of small firm stocks. PR1YR, from Carhart (1997), is a portfolio return constructed by subtracting the returns of a portfolio experiencing low returns in the past 11 months from the returns of a portfolio experiencing high returns in the past 11 months. For HML and SMB, the sample period is 1947:1-1994:12, except for the consumption which is 1959:11994:12. For PR1YR, the sample period is 1963:7-1994:12. 
Table A: Sharpe Classification of Industries, 1947:1-1994:12

\begin{tabular}{|c|c|c|c|c|c|c|}
\hline \multirow[t]{2}{*}{ INDUSTRY } & \multirow[t]{2}{*}{ COMMENTS } & \multirow[t]{2}{*}{ SIC CODES } & \multicolumn{3}{|c|}{ Number of firms } & \multirow{2}{*}{$\begin{array}{l}\text { Fraction of } \\
\text { total market } \\
\text { value } \\
\text { Avg } \\
\end{array}$} \\
\hline & & & Min & Max & Avg & \\
\hline Basic Industries & Chemicals, Mining, Paper, Steel & $\begin{array}{l}1000-1299,1400-1499,2600-2699 \\
2800-2829,2870-2899,3300-3399\end{array}$ & 155 & 377 & 262 & 0.13 \\
\hline Capital Goods & $\begin{array}{l}\text { Computers, Electronic Equipment, } \\
\text { Industrial Machinery, Instruments, } \\
\text { Machinery }\end{array}$ & $\begin{array}{l}3400-3419,3440-3599,3670-3699 . \\
3800-3849,5080-5089,5100-5129, \\
7300-7399\end{array}$ & 105 & 1571 & 629 & 0.11 \\
\hline Construction & Lumber, Stone Clay and Glass & $\begin{array}{l}1500-1999,2400-2499,3220-3299, \\
3430-3439,5160-5219\end{array}$ & 23 & 227 & 121 & 0.02 \\
\hline Consumer Goods & $\begin{array}{l}\text { Apparel, Food, Furniture, Leather, } \\
\text { Motor Vehicles and Equipment, } \\
\text { Printing, Rubber, Services, } \\
\text { Tobacco, Wholesale and Retail } \\
\text { Trade }\end{array}$ & $\begin{array}{c}0000-0999,2000-2399,2500-2599, \\
2700-2799,2830-2869,3000-3219, \\
3420-3429,3600-3669,3700-3719, \\
3850-3879,3880-3999,4830-4899, \\
5000-5079,5090-5099,5130-5159, \\
5220-5999,7000-7299,7400-9999\end{array}$ & 376 & 2707 & 1356 & 0.33 \\
\hline Energy & Petroleum and coal & $1300-1399,2900-2999$ & 42 & 420 & 171 & 0.14 \\
\hline Finance & Insurance, Real Estate & $6000-6999$ & 38 & 2166 & 619 & 0.10 \\
\hline Transportation & $\begin{array}{l}\text { Transportation Equipment, } \\
\text { Railroads, Air Transportation }\end{array}$ & $3720-3799,4000-4799$ & 105 & 216 & 151 & 0.04 \\
\hline Utilities & $\begin{array}{l}\text { Communications, Electric, Gas, } \\
\text { Sanitary Services }\end{array}$ & $4800-4829,4900-4999$ & 48 & 329 & 177 & 0.14 \\
\hline
\end{tabular}




\section{Figure 1}

\section{Industrial Production Growth}

Monthly Data, 1947:1-1994:12

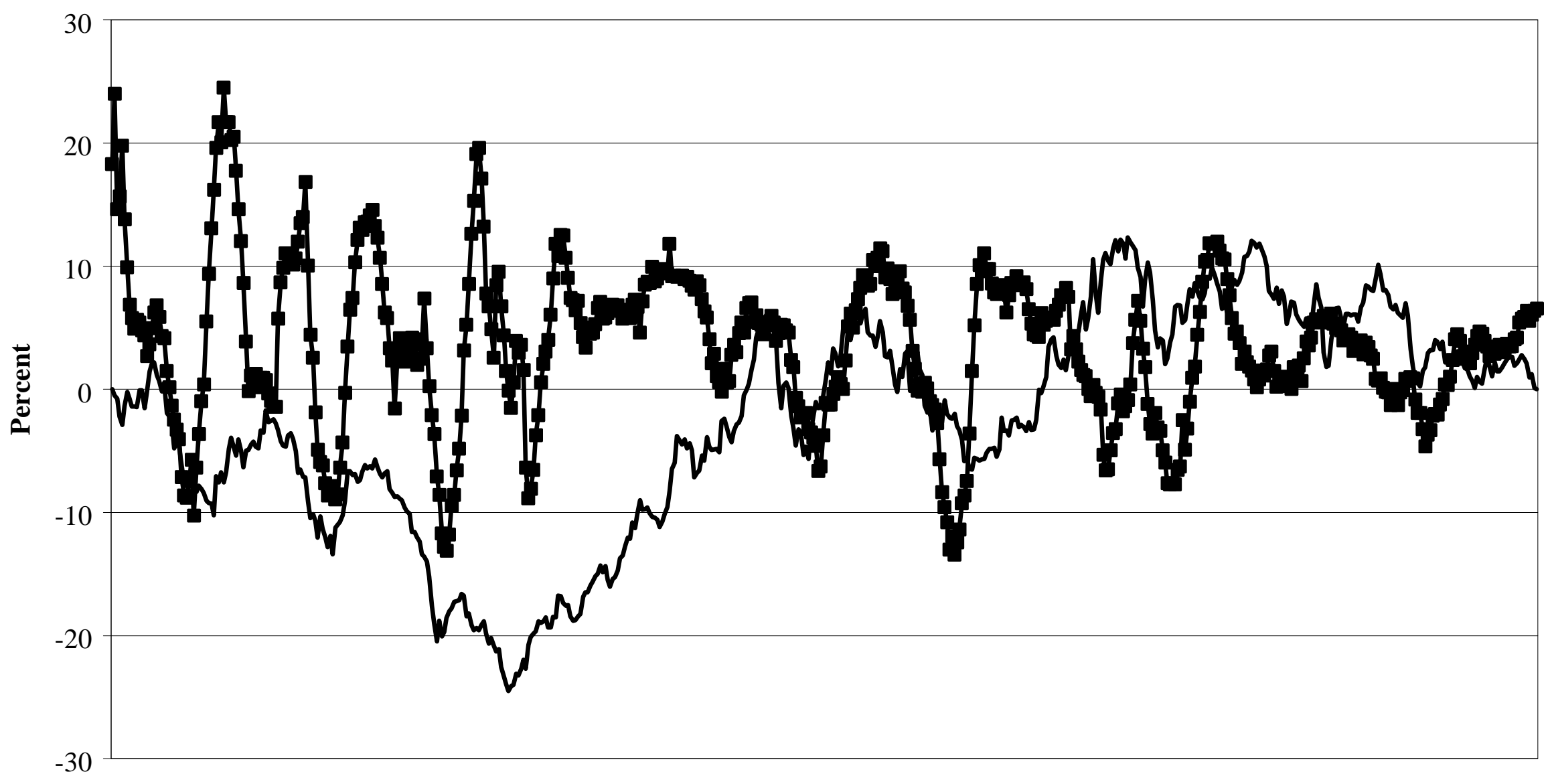

474849505253545557585960626364656768697072737475777879808283848587888990929394

- Cumulative Unexpected Tracking Portfolio Returns

Realized Industrial Production Growth 


\section{Figure 2 \\ Inflation}

Monthly Data, 1947:1-1994:12

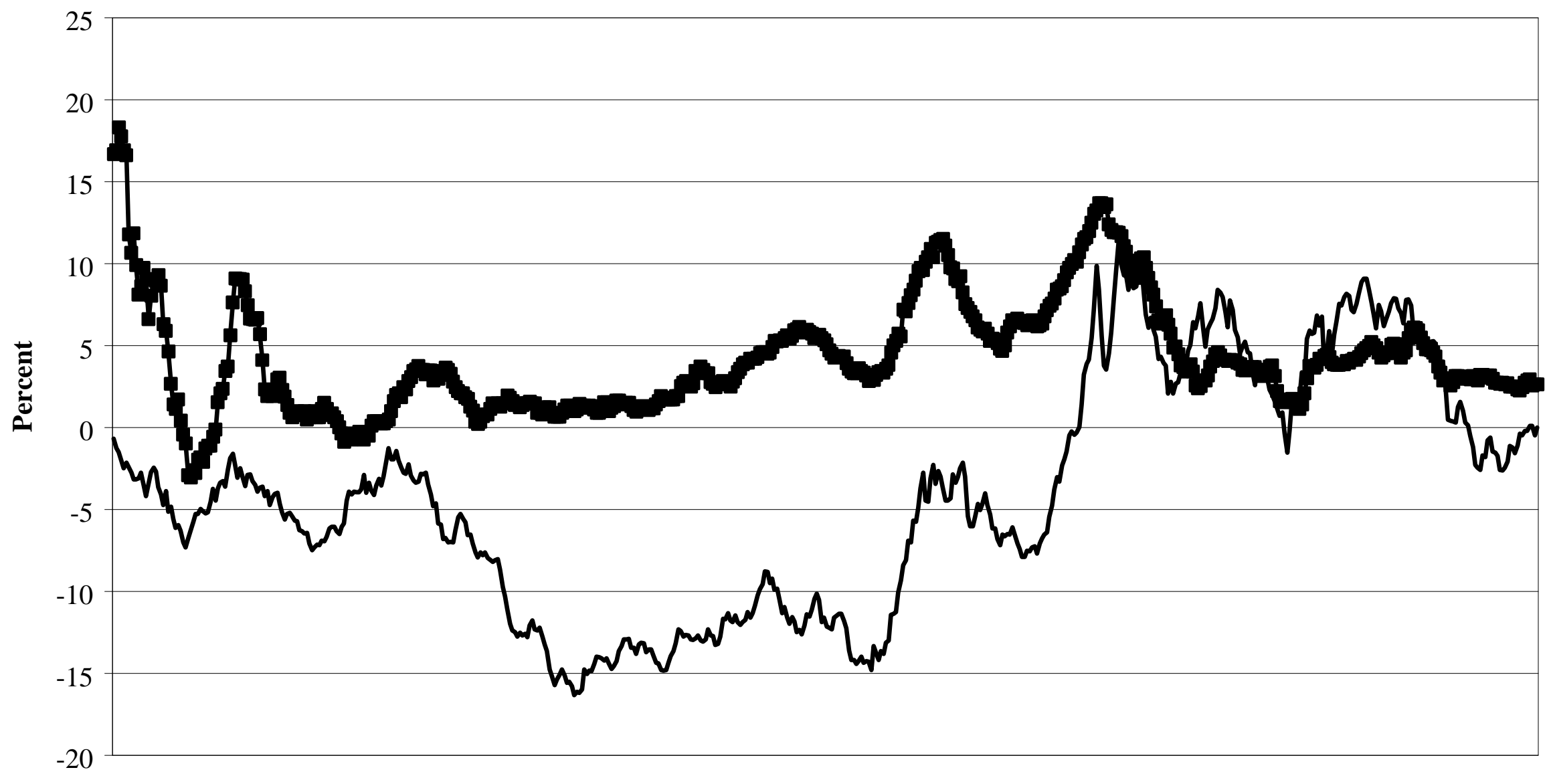

474849505253545557585960626364656768697072737475777879808283848587888990929394

- Cumulative Unexpected Tracking Portfolio Returns $\rightarrow$ Realized Inflation 
Figure 3

\section{Excess Stock Returns}

Monthly Data, 1947:1-1994:12

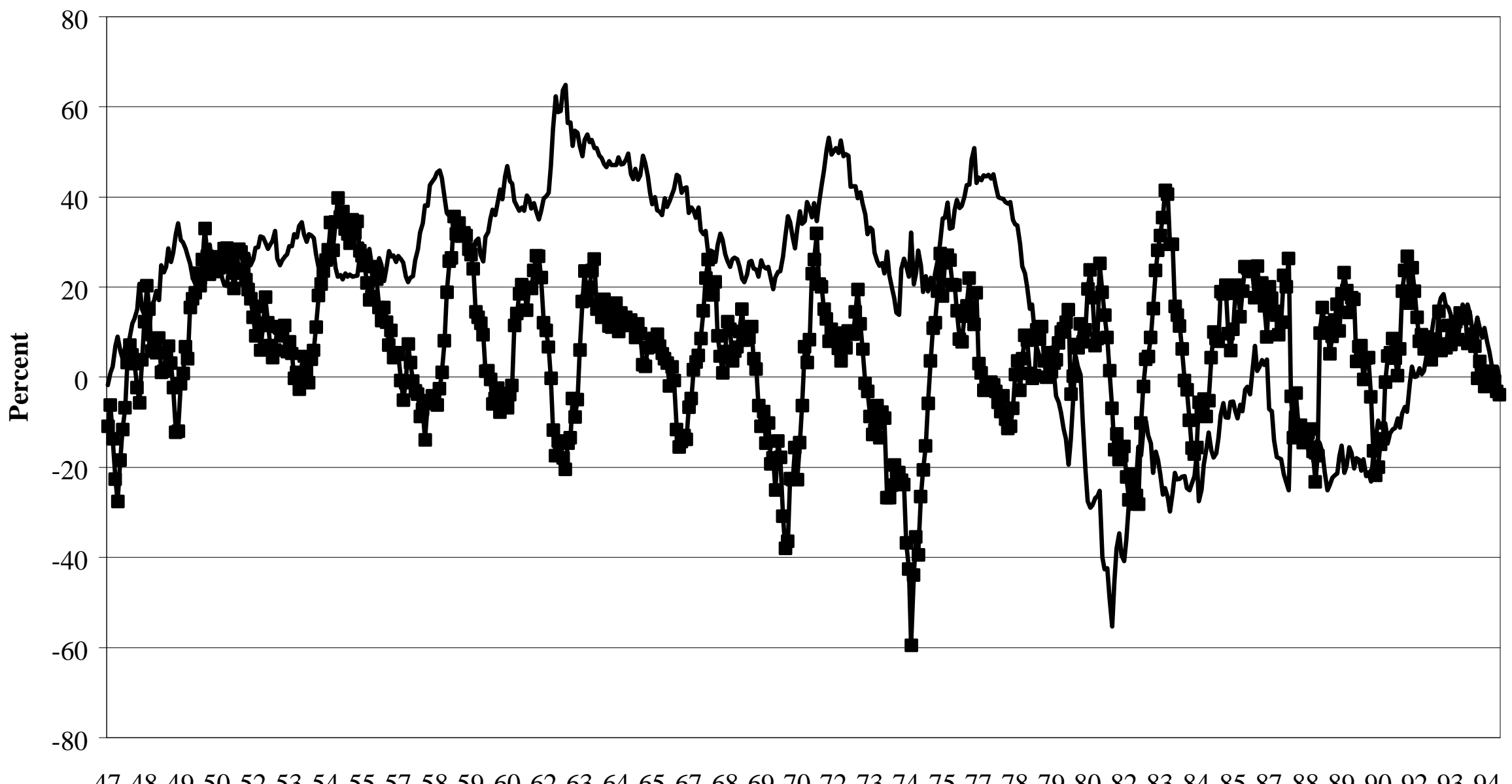

$\longrightarrow$ Cumulative Unexpected Tracking Portfolio Returns $\rightarrow$ Realized Excess Stock Returns 


\section{Notes to Figures 1, 2, and 3}

The figures show cumulative unexpected returns on the tracking portfolios defined by Table 2. Unexpected returns are calculated as the residual, $\tilde{\mathrm{r}}_{\mathrm{t}-1, \mathrm{t}}$, from the regression $\hat{\mathrm{b}} \mathrm{R}_{\mathrm{t}-1, \mathrm{t}}=a \mathrm{Z}_{\mathrm{t}-1}+\tilde{\mathrm{r}}_{\mathrm{t}-1, \mathrm{t}} \cdot \tilde{\mathrm{r}}_{\mathrm{t}-1, \mathrm{t}}$ is summed to make cumulative returns. Realized production growth is (in percentage points) the change in natural $\log$ of industrial production from month $\mathrm{t}$ to month $\mathrm{t}+12$. Realized inflation is (in percentage points) the change in natural $\log$ of the CPI index, from month $t$ to month $t+12$. Realized excess stock return is the continuously compounded total return, in percent, on the CRSP value weighted NYSE/AMEX/NASDAQ portfolio, minus the continuously compounded return on a portfolio of Treasury bills, from month t to month $t+12$. 